\title{
Horse Riding and Wheeled Vehicles in Ancient Arts and Archaeological Evidence
}

\author{
Masumi SUEZAKI \\ Equine Museum of Japan, Equine Cultural Affairs Foundation, 1-3 Negishi-dai, Naka-ku, \\ Yokohama 231, Japan
}

(Received 23 July 1993)

In regards to the beginning of the domestication of the horse, from studies of the remains of horses excavated from the Dreivka remains of a sedentary cattle keep in the middle Dnieper Region of the Ukraine, it was found that the horse had been useful as a domesticated animal in 4,000 B.G. Also, from perforations in the antlers, it was thought that as there were bridles with cheek pieces and, further, no wheels, sleighs and plows, there exists a high possibility that the horses were used for riding purposes. In this way, the use of the horse for riding had its beginning with the stock farmers in the Ukraine and gradually spread to the steppe areas. On the other hand, in regards to the use of vehicles and horses, in Mesopotamia, pictographs have been excavated from the Uruk strata in 3,200-3,100 B.C. which depicted wheels. However, these wheels used primitive wooden boards and, from material of the Ur Dynasty of the early Sumer, it is recorded that these carriages and chariots were drawn by donkeys and Onagers.

Soon, also in Mesopotamia, horses were introduced through interchanges with the nomads and, conversely, the wheel culture was conveyed to the steppe areas. And, in Babylonia, spoke wheels also made their appearance which provided more maneuverability for the chariots. It was thought that these were innovations by the Indo-European Hurrians, Hittites, etc. Meanwhile, in the Orient, traditionally, vehicles were drawn by cattle, or, donkeys, which led to riding donkeys, or, cattle. However, from about 1,500 B.C., riding customs spread throughout the Eurasia Steppe areas, which also led to the beginning of the west Asia Luristan Bronze culture in which metallic bits were inverted. Through the advent of the metallic bit, it became possible to control rough and powerful horses which triggered great changes in world history. And, horse riding and wheeled vehicles spread to ancient Egypt, India, Greece and Rome.

In ancient Greece, chariots existed about 1,500 B.C. and in Greece, horses were given privileged status as mysterious animals akin to the gods, and in various forms, they are reflected in both the arts and mythology. They are Pegasus and Centaurs.

About 2,000 B.C., in the Eurasia Steppe areas, horse riding became popular and from about the 9 century B.C., the Kimmerians recorded in Assyrian literature and the full-scale nomadic Scythians made their appearance. Born were such nomad powers as the Saka in Central Asia, the Yuezhi and Xiongnu in the east. It is possible to see on many gold articles the daily lives and customs of these nomads.

According to mythology, the domesticating of horses in China had its beginning before the Hsia Dynasty but there was no archaelogical evidence before Shang Yin (1,500 B.C.) in east Asia but remains of carriages were excavated in Anyang Henan Province and carriages appear inscriptions on oracle bones.

Basically, the east Asia carriage matches the west Asia carriage, but the east Asia carriage wheel spokes were characterized by multi-spoke wheels. This type of carriage developed during the Chou Dynasty and it can be said that the carriage attained its peak of development during the Ch'in Dynasty through the excavation of a bronze carriage from the mausoleum of Emperor 
Qin Shihuang.

Later, the Han Dynasty which unified China, in order to oppose the nomads from the north, organized a similar cavalry corps by reorganizing the armed forces which consisted of the traditional heavily armed infantry and chariots. And, in 101 B.C., introduced were bloodsweating horses of the west and fine steeds called Pegasus. The pictographs of these fine steeds were depicted in the wall paintings and on pottery. On the Korean Peninsula, the le lang jun was established by the Han Dynasty in 108 B.C. which brought about cultural influence from China which is evident in the bronze carriage equipment for horses and vehicles. On the other hand, prior to the Chinese influence in the northern part of the Peninsula, it is thought that there was cultural influence from the nomads from the north.

On the Peninsula, greeting the 5th century Three Kingdoms Period (Koguryo, Silla, and Paekche), metallic bits made their appearance which popularized riding. As can be seen in the Koguryo wall paintings, cavalry battles were fought and actual chamfrons were excavated from the tomb at Pokch'on-dong, Pusan City. And, these chamfrons and other horse equipment were also introduced to Japan from the end of the 4th century to the beginning of the 5 th century. Later, this horse equipment laid the foundation for the development of horse culture in Japan.

In addition, it was conventionally thought that there were remains of horses on the Japanese Islands of the Jomon and Yayoi periods but, recent research of the remains of horses for whom the periods of existence were certain brought about a reconsideration of the period to be roughly after the 5 th century.

Key words: ancient art, archaeological evidence, horse riding, wheeled vehicle

Jpn. J. Equine Sci. 4(1): 1-23, 1993

一総 説一

\section{美術・考古資料に見る古代の騎行・車行}

\section{末崎真澄}

馬事文化財団 馬の博物館 $\overline{\mathbf{T}} 231$ 横浜市中区根岸台1-3

目次

1. はじめに: 馬の家畜化について
2. 騎行・車行の始まり
3. 騎行・車行の伝播
4. ニーラシア遊牧民の騎行・車行

5. 古代中国・朝鮮半島の車行・騎行

6. 要約と結び

\section{1. はじめに：馬の家畜化について}

人類が初めて馬を表現するようになったのは， 遙か旧石器時代に遡ると言われている。

フランスのラスコー遺跡には, 「先史時代のシ スティナ礼拝堂」とも呼ばれる洞窟壁画があり, 合わせて約 200 点もの動物が描かれている。それ らは当時の狩猟・採集生活を表わしたものであ り，我々の祖先はこのような生活を $\mathrm{BC} 8,000$ 年 頃まで続けていたものと考学らる。しかしこの
頃から氷河期が終って地球が温暖になり, 海面も 上昇し始める。

オリエント地方では徐々に乾燥化が進んでいっ たと言われている。そしてこの頃には，ヨーロッ パからアジアの北部・中部にかけて拉びただしい 数の馬が分布していたことが化石によって推測さ れている。またこの時期には西アジアで農耕が始 まり，ほぼ同時期に動物の家畜化も始まったとさ れている。 
さてそれでは馬の家畜化は，いつ頃，どのよう な場所で始まったのであろらか。この命題に対し て多くの家畜史家，考古学者が諸説 $[5,6,20$,

21，24，46，48]を述べてきたが，だいたい馬の 家畜化の時期については，それぞれの学説の間に 大きな差異はないとされていた。それは羊の家畜 化が BC 8,000 年頃, 牛が BC 6,000 年頃そして 馬の家畜化は最も遅れて打よそ BC 3,000 年頃と 考えられていた。

しかし，近年，馬の家音化の時期はより古かっ たのではないか，と考えることができる有力な証 拠が新たに発見された。それは，ウクライナのド ニエプル河中流地域, キエフの東南 $300 \mathrm{~km}$ に位 置するデレイフカ遺跡の出土遺物である。

このデレイフカは, $\mathrm{BC} 4,000$ 年紀中頃, スレ ドニ・ストーク牧音文化圈にあたり, 発見された 動物遺体は, 馬の骨が最も多く52頭分, 次に家畜 化されていると考えられる牛が 18 頭分, 羊・ヤギ を併せ 16 頭分, そして家畜化された豚が 9 頭分, 犬が 5 頭分, その汪か野生獣や鳥類, 魚の骨など 多数であった[52]。

ところでこのデレイフカからは多数の遺物に加 光，鹿角を加工したと考兄られる棒状鏡板（銜留 め具) に類似したものが出土した（図 1)。そし て, これらの遺物の年は, 放射性炭素補正值で, $\mathrm{BC} 4,000$ 年前後の補正值が出された $[27,28]$ 。こ の棒状の鏡板類似品は，鹿角製と骨製のもの併せ て 6 点があるが，いずれも完形品ではないが，角 製品には穴が 2 カ所認められており, BC 2,000 年紀-BC 1,000 年紀の銜留 (鐮) に大変似ている

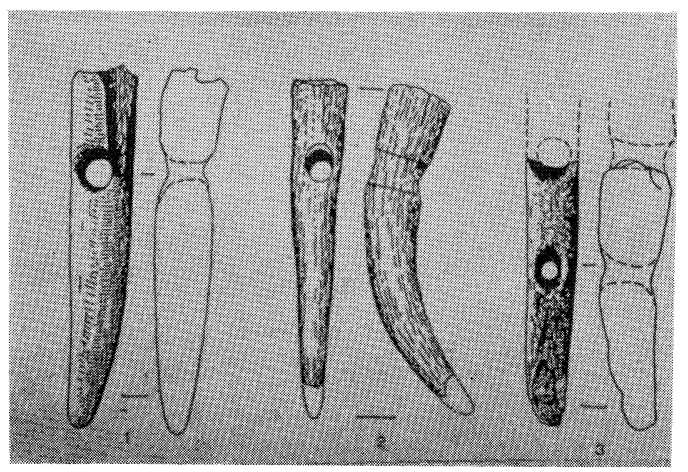

図 1. 鹿角で作られた頭絡の棒状鏡板 デレイフカ出土, BC 4,000 千年頃 (Telegin, D. Y.)
ことで, 最も古い銜の可能性も考えられるように なった。

また Anthony と Brown は, さらにデレイフ カの馬の歯の研究から，通常使役馬（銜をかけた 馬）に扣こる下の歯の第 1 小目歯の前側が斜めに $4 \mathrm{~mm}$ 程擦り減る (bevelling) 形状が数頭認めら れるとした(通常野生馬は，1 $\mathrm{mm}$ 以下) $[2,3] 。$ またLevin はデレイフカの馬骨は，7-8 歳の牡が 多いのは，牧畜群では牡から屠殺するから馬家畜 化の証拠であり，角製の鏡板は食肉以外の用途に 使われたことを示すとし，車輪や㮃，犁もない ことから騎乗が行われたのではとした。さらに Levin は逆の考光して 7-8 歳が多いのは，野 生の馬とした。つまり野生の馬を狩る場合，馬は 群れを作っており，その群れを守るためおのずと 牡の成馬が犠牲になったものとする。さらに食肉 用として飼育したのであれば，肉質の硬化や発育 の理由で, 通常 2,3 歳で屠殺するのが普通であ りよってこの馬は狩りにより捕えられたとする [27, 28]。

またデレイフカの遺跡では, 明らかに意図的に 並べられた馬の頭骨, 肢骨と 2 頭分の犬の前半身 部分の骨も見つかって拈り，これは馬に係わる何 らかの信仰の最も古い証拠とする[19]。したがっ て, 厳密に言えば，家畜飼養かどうかははっきり しない。しかし角製品が馬を制御する銜の一部と 断定できるなら，馬の家畜としての利用が既に開 始されたとすることができよう。

さて $\mathrm{BC} 4,000$ 年頃には，アナトリア方面で多 くの場所からウマ科の動物の骨が見つかって持り， 西アジアでは古くからウマ科の家畜化が証明され ている[29, 30, 33]。

また，Zarins はメソポタミアに拈いて，BC 3,000 年にはシマウマを除いてウマ科の動物が汪 とんど知られて拈り，異種間の交配によるハイ ブリッド (雑種) も， $\mathrm{BC} 2,500$ 年頃には既に表 われていたとする[55]。

そらして歴史時代に入ると，このウマ科の動物 と人間とのかかわりがさらに顕著となり, 美術表 現に頻繁に見られるよらになる。そこでこれらの 美術表現を通して, 古代に拈ける騎行・車行につ いて紹介する。 


\section{2. 騎行・車行の始まり}

纵ユーラシア大陸に抢忛る騎行の始まり

デレイフカ遺跡の馬の家畜化の痕跡は，それま で言われていた家音化の時期を $\mathrm{BC} 4,000$ 紀にま で引き上げることになるが，遅くとも BC 3,000 年頃までには馬の家畜化が，ターパンの生息地の ウクライナ地方でなされていた。

またこのウクライナを中心に，ユーラシア大陸 のほぼ中央を東から西へ連なって横切っている山 系の高原地帯には，多数の野生馬の生息が推測さ れており 6 报，そして同一带で生活していた人々 は，やがて馬を家畜化して利用しようと考皇るよ らになった。人々は当初，馬の首を縛ったり，馬 の顔や下顎を紐で結んだりしながら馬を御してい たが，やがて BC 3,000 年紀と BC 2,000 年紀の 境目に，ついに馬の口中で，下顎の臼歯と切歯の 間に綱や革紐を入れ，角や骨そして木製の銜留金 具で固定し，馬を制御することに成功したものと 考光られる[19]。

そして，やがて BC 1,500 年頃には青銅製の銜 へと変わっていった。これ以降，馬は騎乗，さら にユーラシアでは遅れて車両にも用いられるよう になり，人類の行動の範囲も格段に広がっていっ た。

端古代オリエントの車行の始末り

馬の家畜化は，先に述べたようにウクライナあ たりの牧畜民によってなされた可能性が高いとし た。一方，馬車についても Piggot は，カフカス から東欧方面で牧畜民によって生み出されたと した〔38-41】。また Tarr の「馬車の歴史」によ ると，「民族学者ビールケトースミットは，中央 アジアのステップ地带はまさにこの道具を考光出 したように思えるという。またウィルヘルム・シ ュミットとコッペル，オズワルド・メンギーンも 車輪とそれに続くワゴンの発明によって文明に貢 献したのが中央アジアの遊牧民の牧夫の可能性も あると考光る」としている[51]。

しかし，牧畜民によってなされたといら考光に は，車輪などの考古学的な遺物が発見されていな い。これに対しメソポタミアで馬車が作られたと いう主張には，考古学的な遺物が出土して掠り証 明されている。

これには Falkenstein[11]，Tarr[51]，そして
川又正智〔22〕は，この最古の車両の資料はメソポ タミアのウルク IVa 層出土の絵文字 (BC 4,000 年紀中頃）とする。

ところで BC 3,000-2, 800 年頃のテル・ハラフ のウルク第 $\mathbb{N}$ 層から発見の鉢にも車輪ともとれる 図柄がみとめられるが，この時期には考古学的な 証拠として未だスポークを用いた車輪は発見され ておらず，原始的な板を用いているのが常であり， スポーク付の車輪は，これよりかなり遅れて登場 する $[51] 。$

次にこのシュメールの馬車の使用を表わした ものとして，ジェムデッド・ナスル文化期（BC $3,100-2,900$ 年頃）で，テペ・ガウラの一番古い 地層から発見された二輪戦車の粘土模型があり, また同じ地層から四輪車を表わす粘土模型も発見 されている。さらに初期王朝期 (BC 2, 900-2, 350 年頃）には実物の車付き運搬具の一部も発見され ている $[26]$ 。続いて同じ初期王朝期には，戦車の 表わされた円筒印章（シリンダー・シール）も見 られるよらになる。そしてハファジャ出土の初期 王朝期の螜には，車輪の回りに既に飾り鋲の表現 がみられる。

この後 BC 2,600 年から BC 2,350 年頃のシュ メール文明の中心地であったウルの遗跡からは実 物の車が出土した。ウルの発掘は Woolley (18801960年）の指揮によるもので，王の葬儀の一端が 明らかとなった。とくに王妃の遺体は, 琵型の戦 車に座って扣り, 引くのはウマ科のオナガーとさ れている。このウルの発見で当時の車行の様子も しだいにわかるようになった。

・ウルのスタンダードに見る馬車（図 2 )

このウルのスタンダードは，英国の考古学者の Woolleyがバビロニアの南部のウルの王墓より発 掘した梯形の箱で，軍旗またはスタンダードと呼 ばれた。

用途は不明だが，木地に瀝青を塗り，背景はラ ピス・ラズリ，人物・動物・戦車などは，貝穀を 切り抜いて嵌め込及，周囲の装飾には，貝や赤石 などを四角形につなぎ，鋸歯文風に配列する。図 像は戦いと祝宴を表わしたものだが，戦車は，2 頭立ての四輪馬車である。とくにこの車輪に注目 すると戦車の車輪は，三つの部分から成る円盤状 の車輪が認められ，この形式の車輪がメソポタミ 


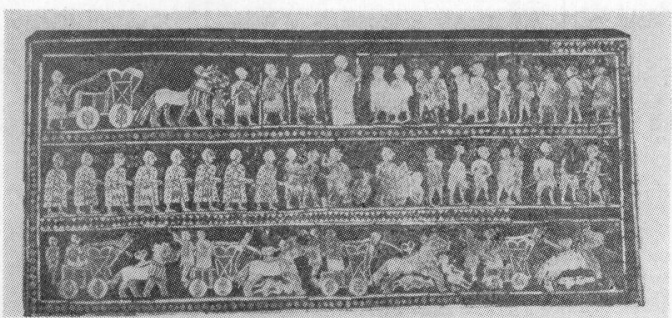

図 2. ウル王の御旗, 戦いの場面 $\mathrm{BC} 2,500$ 年頃, 大英博物館蔵 （大英博物館秘蔵馬のコイン展より）

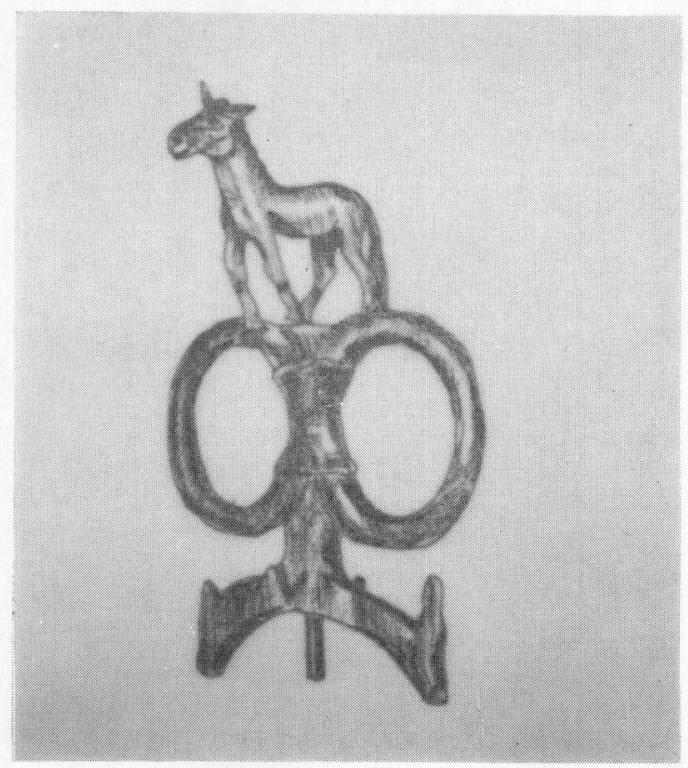

戍 3.手綱通しを飾るオナガー

シュブ・アド王妃の墓室より出土, BC 2,500 年頃, 大英博物館蔵

アで早くから使用されていたことが考えられる。 また図像から，Clutton-Brock は叫輪戦車を引 く動物はウマ科の動物で, 短かめの耳と, 長い四 肢を持ら，尾は房状でその毛量も多いことから， オナガーに近く，あるいは家音口バ/オナガー間 の雑種 (ハイブリッド) とも考えられるとしてい る。また戦勝の祝宴場面の 2 頭のウマ科の動物は, その特徵である肩の線がくっきりと刻まれており， 家畜口バに類似するとしている $[6,7] 。$

このようにロバは, BC 3,000 年紀の初めには, 車による使役の中心となっており, 一方, 馬もや や遅れて家畜化されていったものと考えられる。 つまりメソポタミアでは，ウマ科の動物の使役は,

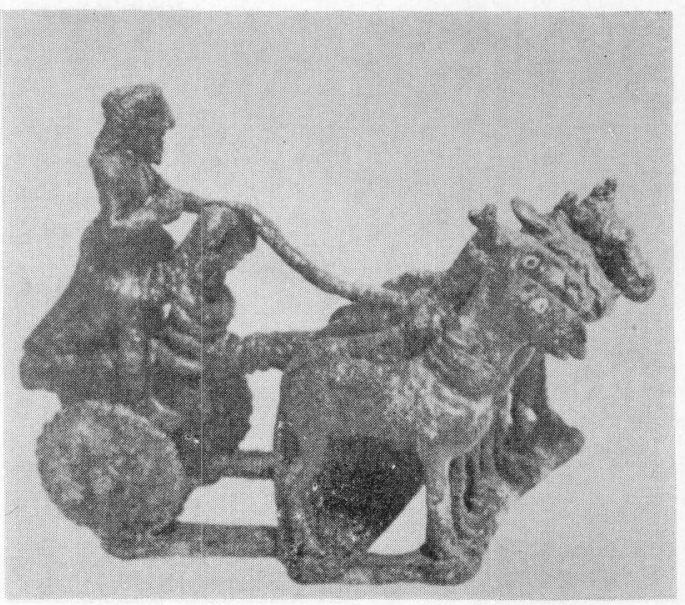

図 4. オナガーの引く戦車像 銅製，BC 2,500 年頃，イラク博物館蔵 (Das Abenteur Pferd より)

馬車や戦車でロバやハイブリッドが先行し，しだ いに力の強い馬へと進んでいった。

・テル・アグラブの戦車像（戍 4)

この戦車(BC 2, 500 年) は, 4 頭立ての野生 ロバ（オナガー）とされる動物に引かれる。戦車 は両輪が両側に在り, 中央に車体があり, その車 体から轅の棒が一本突き出て, 先端の両側に 2 頭, さらにその外側に 2 頭が繋がれている。このよう に当時のメソボタミアでの戦車や馬車の利用に用 いられていたのが，最も身近に繁殖していた野生 ロバ(オナガー）であった。

やがてメソポタミアにも遊牧民との交流で馬が 導入され，逆に車の文化が草原へ伝えられた。こ れはインド・ヨーロッパ語族が馬を伴って中央ア ジアやカフカスを経由して西アジア方面へ移動を 開始したのとほぼ同じ時期と考えられる。

\section{3. 騎行・車行の伝播}

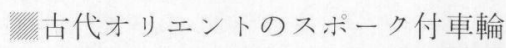
古代オリエントのシューメール人は, 当初車を 牛に引かせていたが，当初の車輪は木を门盤形に 輪切にしたものが考えられるが，考古資料として は 2 〜 枚の板を組み合わせたものであった。や がてバビロニアでは, 戦車にもら少し機動力を持 たせるため, その重量を軽減することが要求され るよらになり, バビロニアではスポーク付車輪が 登場するよらになった $[51]$ 。 
ウル第三王朝 (BC 2,150-1, 920 年頃) が滅んだ 後, オリエントには多くの民族が興亡することと なった。シュメールの後, 登場した古バビロニア のハムラビ王が，BC 1,800 年紀にメソポタミア の統一を果たした。そしてハムラビ法典を残すが， この中には未だ馬の飼育の記録は記されていない。 もっともバビロニアには野生ロバが多数生息して おり既に使役されており，馬がいたことも当然だ が，特段，馬の使役は必要なかったものと考光ら れる。

やがてバビロニアには，インド・ヨーロッパ語 族の山岳民族とされるカッシート人が侵入，この カッシートが馬の飼育を伝えたと言われている $[12,34]$ 。

バビロニアはアジア原産のロバが多数繁殖して いた場所であり, 当初バビロニアには, ウマとい う言葉がなく「東の山のロバ」と呼ばれる程, 外 来のものであった。従って戦車等の利用には, 馬 はほとんど供されていなかった。しかしロバやオ ナガー中心のこの地に馬の飼養を紹介したカッ シートは, 後の BC 1, 600 年紀頃には, この国の 支配者となっていた。

そして以降バビロニアで, 多くの馬が飼養され るようになり，ヒッタイトの王ハットゥシリ 3 世 がバビロニアの王カダシューマン・エンリル 2 世 にあてた手紙に「わが同胞の貴国には, 葍の数よ り馬がいる」と記される程になった。この後古代 オリエントの各地には BC 1, 700 年紀頃からは, 馬と戦車を伴った文化が出現するようになる。 その馬と戦車を結びつけた民族としては，BC 1,900-1,800年頃に北メソポタミアに勢力を持っ たインド・ヨーロッパ語族のフルリ人，そして小 アジアを支配したヒッタイト人 (BC 1, 750-1, 190 年)などが考光られている。とくにヒッタイトは， エジプト，バビロン，ミタンニに並ぶオリエント の強国の一つで, 車輪の改造を行ったとされ, そ の車輪の材料として必要な西洋杉の供給を北方の ミタンニに確保していたのである。ヒッタイトは スポークのある車輪を作り，車を軽くすることに 成功したものと考光られる。 $\mathrm{BC} 2,000$ 年紀の初 期に沶いて, 以前の野生口バの率引利用から新し い率引利用として馬の利用に変えたこと，そして 大工技術の発達を基礎とし，スポーク（輻）を発
明したことは，歴史上画期的なことであった。そ れは二輪馬車の軽量化と弾力性を結合することに よってスピードという新しい要素がもたらされた からであった。

こうしてヒッタイトは, 鉄製の武器を持ち, 馬 に引かせた大量の戦車を戦いに投入して，小アジ アやシリアを征服した。とくに大量の馬の引く戦 車の登場は，あたか子第一次大戦に登場したタン クのようなものであったと思われる。ところで,

Moorey は BC 2,000-1,500 年の近東に打ける戦 車の出現については，あらゆる点を考慮しても， 近東ではウマ科の動物もしくは八イブリッドとの 車の結合が初めてなされたのは BC 3,000 年紀と する。よって近東の軽戦車は, BC 2,000 年頃, 北方や東方から突然侵入した民族によってもたら された革新ではないとした〔34]。いずれにせよ馬 による軽戦車は, やがて有力な武器となり, 古代 オリエント一帯, ギリシアやエトルリア, そして エジプトにも伝光られた。

端古代オリエントの騎行

古代オリエントの騎行は BC 2,000 年頃から何 回かにわたって移動してきたインド・ヨーロッパ 語族の移動とともに始まったと考光る研究者が多 い。オリェントでは, 馬の使用以前から, 牛や口 バに車を引かせて扣り，またDalleyは，そのロバ への騎乗 $[8]$, さらに Downs は, 牛や象への騎 乗もあったとする[10]。その後オリエントでは口 バや牛に引かせる傾向は長く続き，ヒッタイト， そしてアッシリアの時代も続いた。

一方, 馬に直接乗る風習はユーラシアの草原地 帯の牧畜民の間で始まり, 西アジアでは辺境地帯 とされるコーカサスやザグロス山中の山岳地帯あ たりでも広まったと考光られる。

とくに西アジアでは, BC 1,500 年頃から山地 騎馬民族の文化とされるルリスタン青銅器文化が 起こっているが，このルリスタンの青銅製銜がザ グロス山中より数多く出土している（図 5 )。

これは馬が家畜化された当初は, 馬具は角や骨 製の鏡板，そして綱や革紐などで構成していたが， 青銅器文明の発展の過程で, この金属に改良され， ルリスタンで花開いたものと考兄らる。しかし この金属性の銜の発明は, 世界史を塗り替劣る大 变革のきっかけともなった。従来は馬は戦車を中 


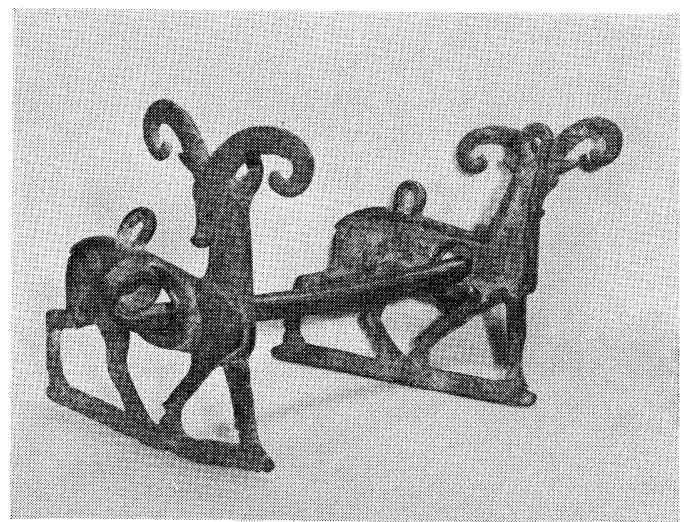

図 5.ルリスタンの銜 BC 1, 000 年紀, 馬の博物館蔵

心とする利用であったが，荒々しく，力の強い馬 も強力な銜の登場により，充分に制御できるよう になり，騎馬術の格段の進歩を促したのであった。 一方，鞍の発達は，これよりかなり遅れる。鞍は 当初は, 馬膚が滑らないよう裸馬の背に簡単な敷 物か布を置き，これを縄または紐で縛り，馬上で の安定を図ったのが始まりであった。

・アッシリアのレリーフに見る車行・騎行

アッシリアは, 北メソポタミアの主用通商路に 沿って台頭し，BC 1,300 年紀までに西アジアの 軍事強国となっていた。まず隣接していたバビ口 ンを攻略，中期アッシリアの王アッシュールウバ リッド（BC 1365-1330 年）は北のミタンニを抑 光, ヒッタイトやエジプト, カッシートとも親 交を深め国力を充実させていった。そしてアッ シュールナシルパル 2 世 (BC 883-859 年), シャ ルマネセル 3 世: (BC 858-824 年), ティグラト・ ピレセル王（BC 744-722 年)，拈よびアッシュー ルバニパル王（BC 668-627 年）の治下でその勢 力は頂点に達した。そしてアッシリアはシリア， パレスチナを征服，エジプト，エラムをも併合し た。この強力な軍事国家は，基本的には戦車部隊 と歩兵部隊から成っていたが，何と言ってもアッ シリアの軍隊の軍事的優位を成していたのは馬と 騎馬軍団であった。しかしアッシリア人が馬の持 つ戦略的重要性に気づいたのは, 他のオリエント 諸国に比較してやや遅かったようである。ところ で野生口バや馬, 戦車, 馬の飼養, 調教方法等に ついては，その軍事史とともに，数十万点に及ぶ 楔形文字の粘土板に記されている。またシャルマ

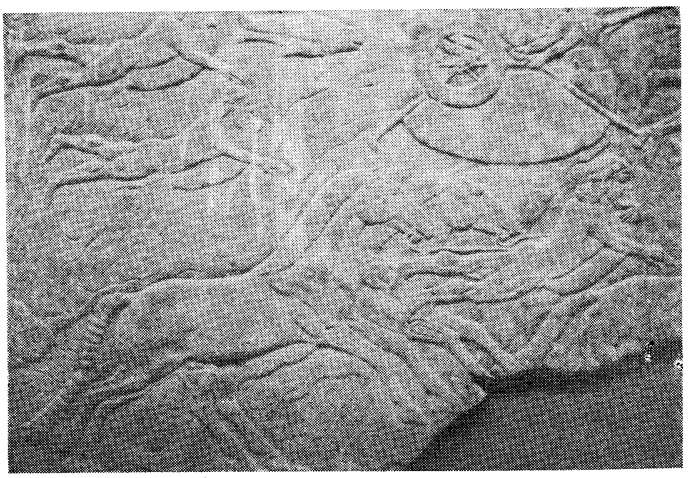

図 6.アッシュールナシルパル 2 世の川を渡る情景 ニムルド出土(BC 883-859 年), 大英博物館蔵 (Assyrian Sculpture-British Museumより)

ネセル 3 世の宮殿の青銅製の門 (バラワート), ティグラト・ピレセル王，アッシュールナシルパ ル2世，アッシュールバニパル王の宮殿のアラバ スター製のレリーフにも図像として詳細に表わさ れている。これらの粘土板の記録には，BC 9 世 紀の頃, 北ウラルトゥの戦いに, 戦車が 106 台, 騎兵が 9,374 騎, 歩兵が 20,270 名が投入された記 事も含まれている。

・アッシュールナシルパル 2 世の川を渡る戦車 之馬 (図6)

このレリーフは，アッシュールナシルパル 2 世 の軍事行動を主題として描いたものである。眓像 は，ユーフラテス川を越えて進軍するアッシリア の部隊を表わすが，兵士達は，羊の革袋を空気で ふくらませ浮袋とし，泳いでいる。綱代舟には王 の戦車を積み，櫓を漕ぐ兵士，船上には二頭ずつ の馬の手綱を両方の手で持ち泳がせる御者が乗る。 馬は口中に紐を通し，下顎を縛られている。この 場面には，革袋につかまりながら馬とともに泳ぐ 兵士の場面もあり，興味深い。

・アッシュールナシルパル王のキャンプ(図 7) アッシュールナシルパル進軍中のキャンプを表 わしたもので, キャンプ中の風俗が良く描写され ている。左側の四等分した円形のものは, 建物の 内部を上から望み，室内は真横から見る。中には 人々が食事の準備や儀牲獣による占いをする人々 などが表わされている。

一方, 右側の場面は, 柱の先端に野生ヤギの装 飾のついた王の天幕の手前で, 穀物を与兄られる 馬，鉄櫛による馬虐の手入れなどが表わされてい 


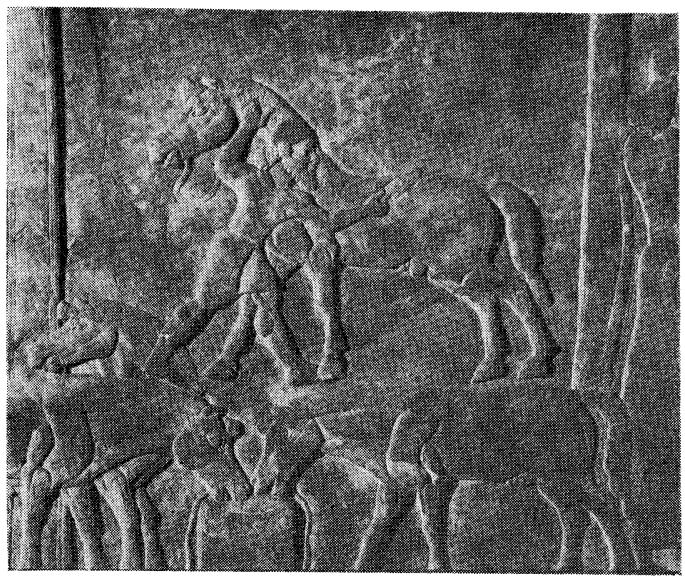

図 7.アッシュールナシルパル王のキャンプ

ニムルド出土 (BC 865 年頃), 大英博物館蔵 (Assyrian Sculpture-British-Museum より)

る。

さて馬の手入れなどについては，BC 1, 400 年 頃にミタンニ王国の調教師キックリが記した戦車 馬の調教規程が知られている。

メソポタミアでは，フルリ人 (ミタンニ) やヒ ッタイト人との交流で，既にロバやオナガーの飼 育・調教の知識も豊富であった。これに加光カッ シート人の侵入もあり，アッシリアでは，打拈む ね，これらを伝統的な規箸としていた。そこで キックリの規程について簡単に記すと，まず手入 れでは，鉄櫛による皮膚の手入れ，1日 6 回の水 浴び(ヒッタイトでは 9 回), 油または羊脂の塗付 けとマッサージ，汗やほこり落としなどが書かれ ている。穀類は，大麦や小麦を炒ったもの，乾燥 させたものあるいは湿らせたもの，麦芽，混合飼 糧, 新鮮な草, または乾草, とくに牧草と切り葍な どである。この穀類飼料の給養基準としては「一 握り」が尺度であり，1日2握り以上は与えない とする。また馬の水の飲ませ方，排水を良くする ため塩水ないし麦芽汗を飲ませるといったことな ぞ詳しく記されている〔14]。これらの規程にもと づく手入れ方法や，飼料の給養をアッシリア人が 全てとったかどうかは未だはっきりしないが，こ のアッシリアのキャンプの表現は, 当時の馬のグ ルーミングを表わした貴重なシーンである。

・アッシュールバニパル王の狩猟図（四８）

ニネヴェの宮殿に飾られていたアッシュールバ ニパル王の狩猟図，とくに勇壮なライオン狩りの

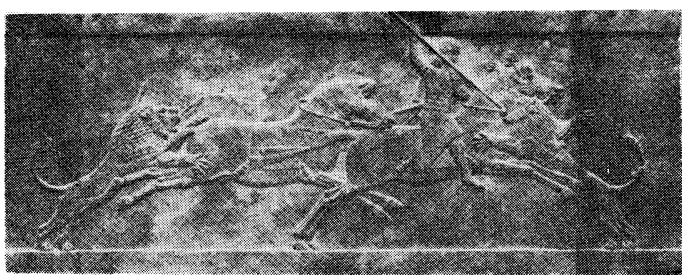

図 8.アッシュールバニパル王のライオン狩り ニネヴェ出 (BC 645 年頃), 大英博物館蔵 (Assyrian Sculpture-British Museumより)

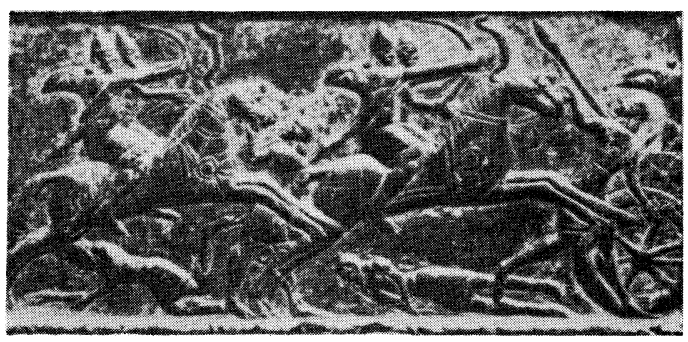

図 9. シャルマネセル 3 世, バラワート門, 青銅 BC 859 年, 大英博物館蔵

(Assyrian Sculpture-British Museumより)

描写は，今日アラバスター彫刻の傑作として知ら れている。この作品では，王の乗る馬は前髪を編 み，胸慗に房飾りをつけ，頭絡には少し曲がった 棒状の鏡板（煩当）が表わされる。鞍はカーペッ 卜状の鞍敷により身体を安定させている。王の狩 猟の対象とされ，犬に追われるウマ科の動物は， 当時近東に広く分布していた野生のオナガー（市 るいは絶滅したシリアノロバ）を表わしていると する[6]。

ところでアッシリアの馬の外観について見てみ るとシャルマネセル 3 世 (BC9 世紀)のバラワー 卜の青銅製浮彫り（図 9 ) 飞は，戦車や乘用に胴 の長い馬が表わされている。しかし後のアッシュ ールバニパル王の時代の馬は，今日のアラブ馬の 愛好家が理想像と見なす，馬体が “正方形”に近 い外観を成している。また尾は，旧来のそれより も高い位置についている。馬の顔付も鼻梁が軽く 䆶み，やや凹字形を呈している。これらは全て今 日の東洋馬の特徵となっていることは言うまでも ない(図10)。この馬格の変化理由としては, アッ シュールバニパル王の数代前までに再編されたと 考光られる戦車主体の軍団から騎馬主体の軍団へ の変更が考えられる。そうしてこのようにBC 9 世: 


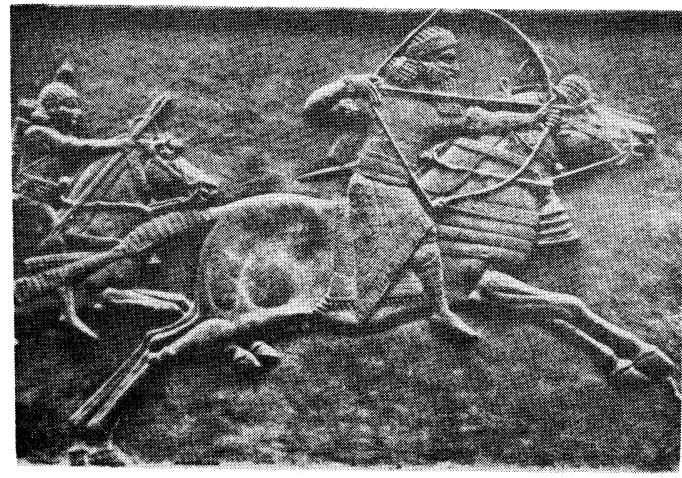

図 10.アッシュールバニパル王の狩編図 ニネヴェ出土 (BC 645 年頃), 大英博物館蔵 (Assyrian Sculpture-British Museum より)

紀のアッシリアの乗馬（図 9) は，弓矢を射よう とする騎手の横に手綱を持つ兵士が併走するのに 対して，BC 7 世紀には，騎手はしっかりと騎座 飞安定し, 王の狩猟図でも王は手綱を併走の騎手 に持たせず一人で弓を射るように描かれている (図10)。

なお川又正智は, 古代文明地带では一時期 (BC 2,000 年頃メソポタミアなど）には，馬の腰から 尻にかけて騎すことも行われたとする。資料は多 くはないが，鼻輪を使用していたようであり，研 究者のあいだでは「驉馬のり」と称されている。 ふるく牛に乗っていた技術が馬に応用されたかと も思うとしている[8，22]。

ところでアッシリアは何世紀にもわたって，軍 事組織と進んだ兵器によって，その隣人達を支配 していたが，ウラルトウ，バビロニア，エラム人 もアッシリアの戦術をすぐ学んだ。よって彼らも 騎馬戦士と戦車の独占状態を失うにあたり, 最早 や優れた武器を保有する唯一の民族ではなくなっ た。そしてアッシュールバニパル王の二世の時代 までにカルディア人，アラブ人，ェジプト人，ェ ラム人, メディア人の全てが騎馬術を学び, 攻撃 的な敵対者に成長し, ついにアッシリア帝国は滅 んだ。

次にバビロニアを支配したのはペルシア人で あった。そのペルシア人は, 戦車にかわってさら に騎馬軍団を充実させたのであった。もっともぺ ルシア王キュロス 2 世は, 戦車への執着が強く, 8 頭引きの戦車を用い, ダリウス 1 世 (BC 522-
486 年）は，いまだに戦車に乗った姿で表わされ ている。またダレイオス 3 世（BC 335-330 年） は，アレクサンドロス大王との戦いで，モウワー （車輪に鋭い刃をつけた馬車）を200台を子使った ことが記されている[51]。

このペルシアは，アッシリア帝国の道路網を引 継ぎ，さらに延長して整備を図った。ギリシアの 史家へロドトスによると，ギリシア海(エーゲ海) からいわゆる「メムノンの都」スサまでの全行程 は，14, 400 スタディオン $(2,664 \mathrm{~km})$ で, $111 の$ 宿泊所があった [32]。つまり, 約 $24 \mathrm{~km}$ の間隔で 宿駅が設けられていたのである。

约古代ェジプトの車行

戦車が古代ェジプトへ伝えられたのは， BC 1,670-1,570年頃のヒクソスの侵入によってで あった。彼らの軍隊が侵入して来るまで, エジプ トでは何世紀にもわたって無敵であった。しかし 戦車で武装したヒクリスは, シリアとパレスチナ を征服し，BC 1, 650 年には，エジプトをも支配 した。エジプトは, それから 1 世紀後に, 彼らの もたらした戦車で武装し, 逆に彼らを駆遂するこ とに成功した。その後エジプトの戦車は第18王朝 (BC 1,567-1,320年頃) から第20王朝 (BC 1,2001,085年頃) にかけてスポークの数も 4 本, 6 本, さらに 8 本スポークヘと変わっていく。とくにラ メセス 2 世のヒッタイトとの戦車戦の行われたカ ディシュの戦い（BC 1, 286 年）を表わしたレリー フには，6本のスポークが見られる。

•テーべ遺跡，ネバマンの壁画（図11）

この壁画は, 第18王朝の貴族ネバマンの墓に, 漆喰に多彩色で描かれたものである。6本のス ポークを持つ軽戦車が表わされる。当時の車輪を 構成する材については, 素材となった材木は車軸 とスポークがトキワガシ, 梶棒はニレ, 輪縁と車 台と泥よけ板はトネリコ, くびきはシデ，スポー クのラッピングと輪縁にスポークを縛りつける軸 頭（ハブ）にはカンバの樹皮が使われていたとい 5[51]。

このよらなエジプトのレリーフに見る馬具は, 馬の頭部の真中に一種の頸帯が巻きつけられ, そ れに手綱が固定され，手綱を引くと馬の首にかか る圧力が増し, 馬が速度を緩めるかあるいは停止 するかする仕組みであった。ところで馬の口中に 


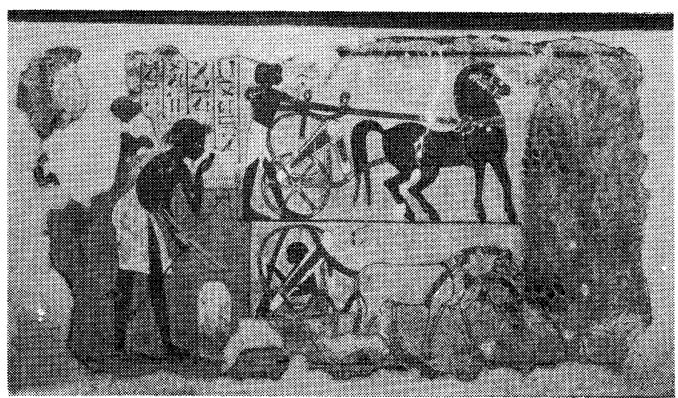

図 11.ネバマンの墓の壁面, エジプトの軽戦車 テーベ (BC 1, 400 年頃), 大英博物館蔵 (Egyptian Painting-British Museumより)

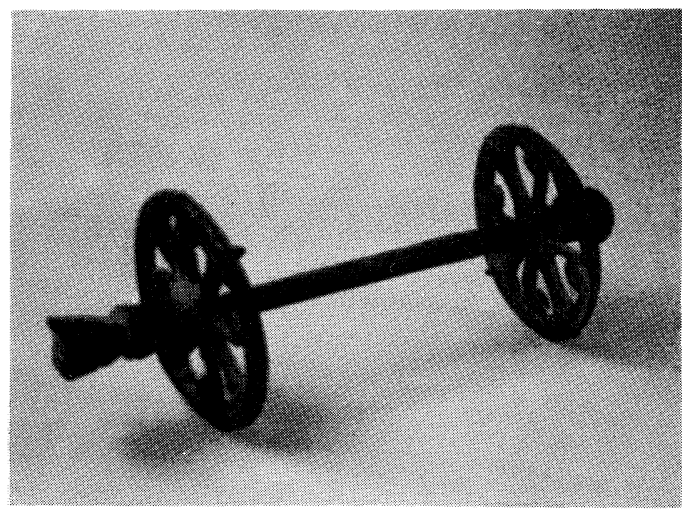

図 12. 青銅の銜

新王国時代，第 18 王朝， BC 1, 340 年頃 ベルリン国立博物館蔵

（大エジプト展より）

入れる金属性の銜は，青銅製の 1 本棒から成る銜 が存在していた（図12）。この金属製の銜は，七 クソスによってもたらされたといわれているが はっきりしない。そして少し後には連結された銜 も使用されるに至った。この銜には馬の口中から 外れないようにする同じく金属製の煩具がつけら れており，この煩具を突くようにした突起が付け られたものがあり，馬に対して強力な責具とも なっていた。しかしェジプトの古王国では，馬は 戦車による利用が中心であり, 騎馬への利用は もっと後のことであった。実際の戦車の遺物も, アメンヘテプ 3 世の雨親の墳墓 (BC 1,375 年), ツタンカーメンの墳墓 ( $\mathrm{BC} 1,350$ 年), テーベの 墳墓（BC 1,500 年）などから，極めて軽量化さ れた戦車が出土している。
的古代インドへの車行・騎行への伝播

インドでは, BC 3,000 年紀に，インダス文明が 栄えていた。この文明を明らかにしたモへンジ ョ・ダロ遺跡からは, 模型の馬車が出土, また道路 の跡も発見された。たぶんにシュメールと同じく らいさかのぼるものであった。その後, BC 2,000 年紀にインド・ヨーロッパ語族の移動が始まり, しだいに彼らはトルキスタンからインダス河畔・ 下流へと進出，そこへ初めて戦車と騎馬の文化を もたらしたとされる。この侵入者であるインド・ ヨーロッパ語族系の民族は, BC 1, 300 年頃に「リ グ・ヴェーダ」の神話を生み出したといわれてい る。このリグ・ヴェーダには，勇猛な神馬に捧げ られた歌が見られ，太陽神スーリアの車の引く金 色の馬や，後世王権の象徴となるアシュバ・メー ダ（馬祀り）に関する歌などが認められる。

经古代ギリシアの車行・騎行

ギリシアでは, $\mathrm{BC} 3,000$ 年紀の前半, 先進のオ リエント文明の影響を受けて，エーゲ文明が栄え， $\mathrm{BC} 2,000$ 年紀前半は, クレタ島にミノス文明が最 盛期を迎えていた。しかし BC 1,600 年頃になる と，インド・ヨーロッパ語族に属するギリシア人 の支派が，ミュケナイ文明を生んだ。このミュケ ナイの堅穴式墳墓などには既に戦車が描かれてい る。

さて馬に引かせる戦車は， $\mathrm{BC} 1,500$ 年頃には ギリシアにもたらされていたが，それは未だ決定 的な役割を果たすまでには至らなかった。戦車は， ギリシア人達が既にェーゲ海の島々に分離してい たことから，実用には適さないものであり，山が ちの本土に拈ける移動の一手段でしかなかった。 よってギリシア人は肥沃なレタンティン平原をめ ぐる戦争が起こる BC 700 年頃まで，騎馬軍団も 有していなかった[9]。

しかしギリシアに打る馬は，初期のどの文明 よりも，遥かに大きな役割を果たしていた。その 役割とは, 馬の特権的な地位であり, 神に近い神 秘の動物とされたことであった。それは芸術と神 話の両方に际いて，それが表現されるさまざまな 姿に反映している。太陽神へリオスの 4 頭立ての 戦車, 暁の女神エオスの 2 頭の馬, 月の女神セレ ネの戦車，翼を持ったペガサス（天馬）など，神 話の中で神とともに表わされた（図13）。 


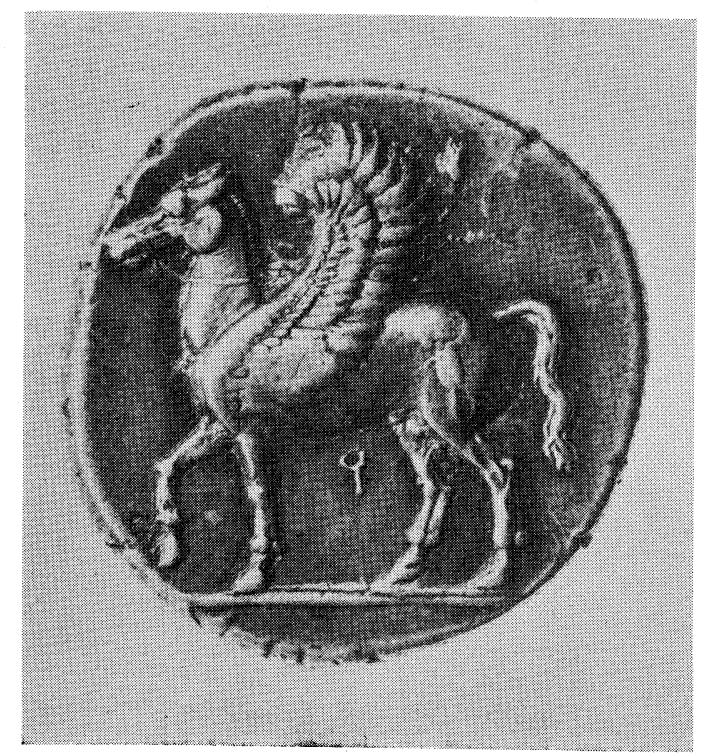

図 13. ペガサス，スターテル銀貨

$\mathrm{BC} 375$ 年頃, ギリシア, コリント

（大英博物館秘蔵馬のコイン展より）

一方，ラバは数多くの諸国で高く評価され，重 要な動物としてしばしば高貴な地位さえ与えられ ることもあったが，ギリシアではもっぱら使役に 用いられたのである。

このように馬は BC 700 年頃までには，戦争の 道具としてょり，狩椫と競走だけに使われるよう になった。これらの戦車は多数の铝絵やコインな ぞの題材に神とともに表わされた。

それらの図から車体が極めて軽く, 車輪の位置 も低く，スポークの数は最初は 4 本だが, 6 本, 8 本と増えて行ったことがわかる。

当既古代ギリシアの戦車競走と競馬（図14）

人々が初めて馬を制御することを習得して以来, 競馬を楽しむため, 競馬を大規模に組織して, 競 馬を開催することを目的としたヒッポドローム (競馬場)を建設したのは，ギリシア人が最初で あった。

その戦車競走による競馬は，イリアスなどで知 られており，ギリシアの様々な地方でずっと以前 から開催されていた。そしてカドリガ（4頭立て の馬に引かせた二輪戦車) 競走が，古代オリン ピック競走に加えられたのは, BC 680 年・第 25 回オリンピックからであった。その競走の行われ るコースはヒッポドロームと呼ばれる棈円形の競

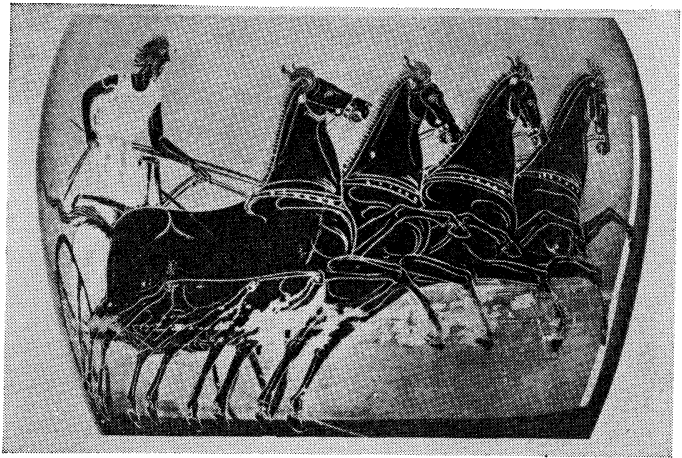

図 14. アンフォラに表わされた戦車競走 BC 5 世紀頃, 大英博物館蔵 $\left(\begin{array}{l}\text { The Ancient Olympic Games; Judith } \\ \text { Swadding-British Museum より. }\end{array}\right)$

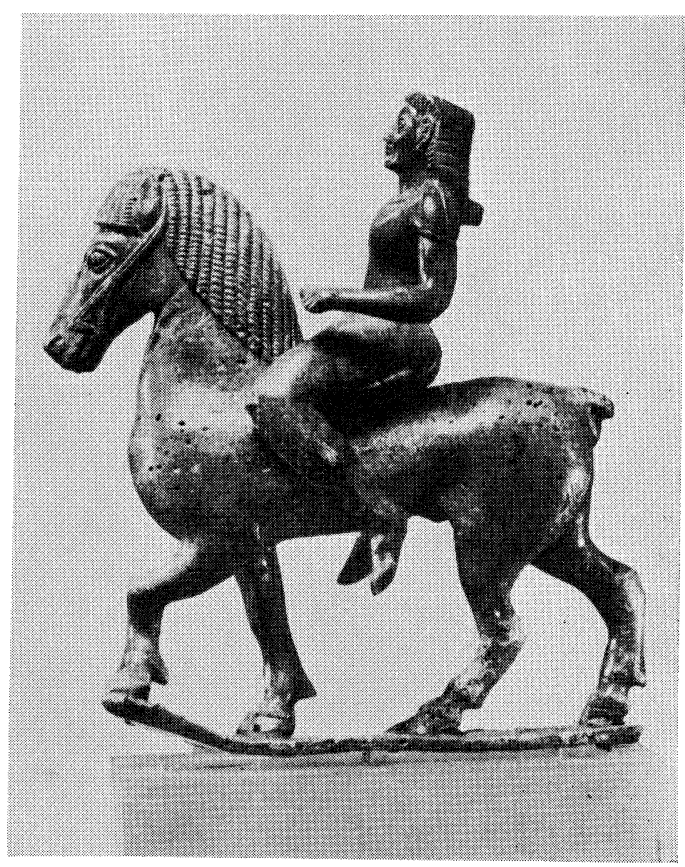

図 15. 古代ギリシアの騎士

ブロンズ, BC 6 世紀, アテネ国立学博物館蔵 (ギリシア政府観光局提供)

技場であり，コースの一周は約 $740 \mathrm{~m}$ で，そこで 催される戦車競走の距離は, 約 $9 \mathrm{~km}$ であった。 ヒッポドロームは, オリンピアを初め, デルフォ イ、コリント，ピュロスにもあった[9]。

その後, BC 648 年に競馬が始まった。この際, 競走者は銜をつけただけで，鞍も鐙もない裸馬に 騎乗し，膝をしめて馬を制御したのであった（図 15)。 


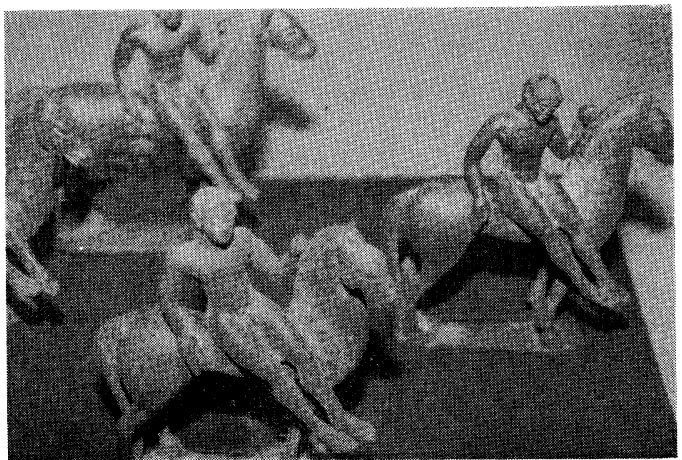

図 16. カルペ競馬 get-off-and-run race 青銅，エトルリア BC 520-500 大英博物館蔵（筆者撮影）

ところでギリシアでは, ペルシア戦争の頃 (BC 480年頃)，新しい競馬競技一牝馬による競馬，い わゆるカルペ競馬（図16）が始まった。この競馬 では, 騎手が競走の最後に馬から跳び降り, 馬と ともに走らなければならなかった。しか子騎手は 手綱を持って走り，人と馬が同時にゴールインす ることが必要であった。

また牡馬による同様な競技，アナバテスと称さ れた競走も行われた。しかしこれらの競技はラバ に上る馬車競走と同様，あまり人気がなく，数回 実施されただけで廃止された[13]。

さて古代ギリシアでは，人間の次に高貴な動物 として馬をとり上げ，神話の題材にもぺガサスや ケンタウロスとして, 多くの彫刻やレリーフ, そ して壼絵コインなぞに表現されている。しかも それらの作品には, 古代ギリシアの馬術家として 知られるクセノフォンの馬術論を反映させた作品 もある。

弪高パテノン神殿のフリーズ

・騎士の行列とセレネの馬

アテネのアクロポリスを飾っていたパルテノン 神殿の大彫刻群は，あまりにも有名だがそれらは 三種類の彫刻から成っており，これらのらち，大 部分は大英博物館にもたらされている。

彫刻群のひとつは，BC 443-438 年制作の神殿 内陣の上部外壁をとり巻く $163 \mathrm{~m}$ に及ぶフリーズ で，この主題は，パン・アテナイ祭（またはマラ トンの戦いの英雄達）の行進と考兄られてた。 この行進には馬が約 200 頭も表わされる。とくに

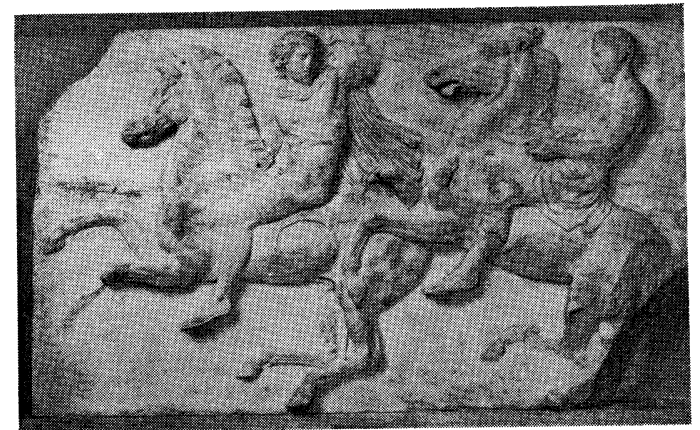

図 17. 騎士達の行列

BC 5 世紀, 大英博物館蔵, ドゥビーン・ギャラリー (The Elgin Marbles-British Museum より)

騎士のパレード（図17）は，その準備作業から始 まり, 騎乗し, 動き出しては止まる, といったバ リエーションで描かれている。騎士は手綱をと り, 裸馬に跨り，馬と騎手は身体を収縮した姿勢 で, 後脚で立つような姿勢がしばしば表現されて いる。

また騎乗のスタイルは, 背峰のすぐ後に座り, 足は滕から下をだらりと下げ，身体の状態を楽に して乗っている。クセノフォンは, 著書「馬術」 の中で，馬の頭や首がとるべき姿勢について厳し く言及している〔36]が，その後，彼の理論は忘れ られ，イタリアのルネッサンスの時期まで顧みら れることがなかった。

な技ギリシアの馬術家では, 馬の専門的な調教 師であるとともに乗馬家であったテアネのシモン (BC 400 年頃) も知られている。

・七レネの馬

二つめの彫刻のうちこの馬の彫刻（図18）は, 切妻の屋根の下を飾っていたもので, 女神アテナ を讃える女神の誕生物語の部分を飾っていた。

ディオニューソスを除き神々は頭部を欠くが， この月の女神セレネの戦車を引く馬の頭部は, 当 時の名馬の条件を表わしたものとされている。突 き出た様な大きな眼, 心蔵や肺機能の発達を象徵 するような大きく開いた鼻孔などが特徵である。

•ケンタウロス（図19）

三つめの彫刻群は, 神殿の外陣上部の外壁を 飾ったメトープで，ギリシア神話の「巨人族と神 々の戦い」,「ケンタウロスとラピタイ人の戦い」 などを題材とする。 


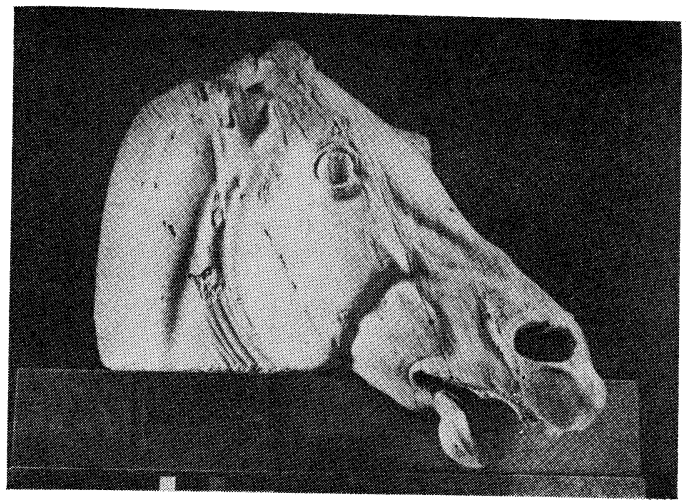

図 18. セレネの馬

BC 5 世紀, 大英博物館蔵, ドゥビーン・ギャラリー (The Elgin Marbles-British Museum ょり)

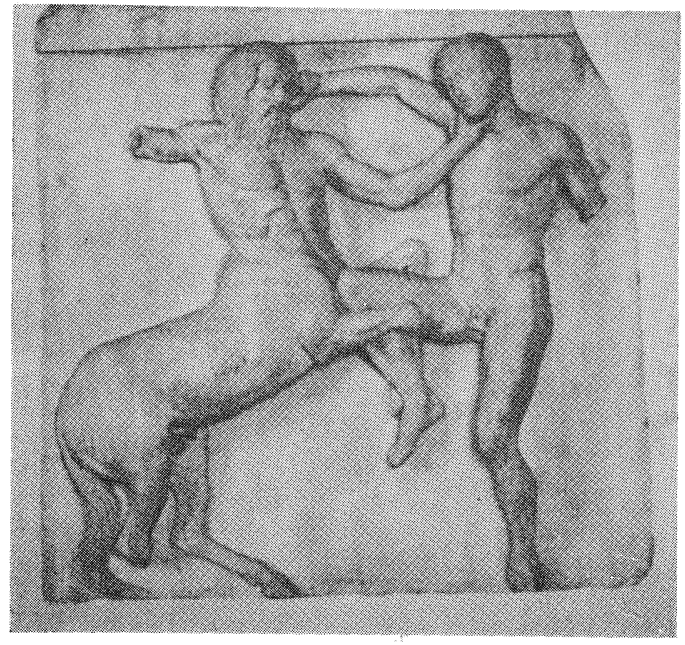

図 19. ラピタイ人とケンタウロスの戦い

BC 5 世紀, 大英博物館蔵

(The Elgin Marbles-British Museum より)

この騎馬文化の伝来を象徵するケンタウロスの 姿は，美術作品に数多く表わされている。

ギリシア人が初めて騎馬の民に出会った際，上 半身が人間，下半身が馬といらケンタウロスの伝 説が生まれたと言ら。そしてその場所はギリシア 北部のテッサリアだと考える。

またその時期は人類が初めて騎乗に成功した後 のことで，ミュケナイが建設される以前， BC 2 , 000 年紀におこったものと推測される。そのテッ サリア平原の人々が出会ったのは, 恐らくキンメ リアなどの原スキタイ人などが考えられているが， はっきりしない。

さて以上の彫刻群は, BC 5 世紀の彫刻家フェ

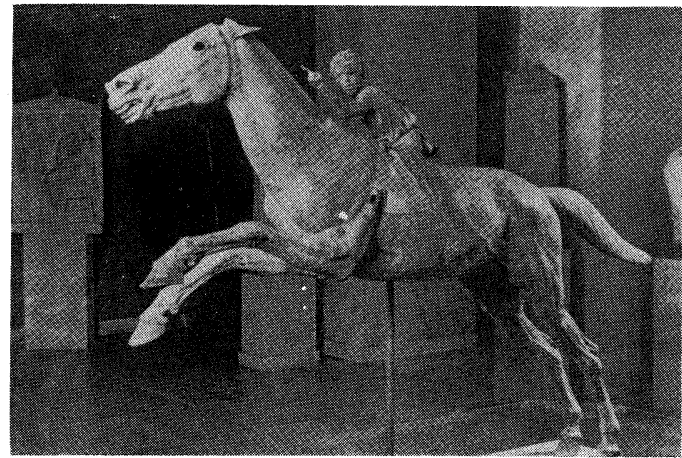

図 20. 競走馬と騎手

ブロンズ, BC 2 世紀

アテネ国立考古博物館

(ギリシア政府観光局提供)

イディアスによって製作された傑作であるが，人 と馬とのバランスは，その芸術的理由から，馬は 騎士に対してやや小さく作られている。そしてこ の彫刻の馬のモデルになったのが古くから駿馬を 産していたテッサリア平原の馬と考えられている。 またその当時の競走馬を表現した傑作も知られて いる(図20)。

この競走馬と騎手の像は, 競走馬の疾走する一 瞬の様子をみごとにとらえて拈り，筇肉や血管の 状態など，その動きまでとらえたギリシア芸術の 頂点に位置する作品である。この疾走表現，フラ インイグギャロップの図像はミュケナイの時期よ り好まれ，世界各地へ伝光られて行った[49]。 その後ギリシアでは，スパルタとアテネがかつ ての隆盛を失なった後，マケドニアが台頭。フィ リップ 2 世（BC 359-336 年）は，騎馬軍団の軍 事的価值を認識し，ギリシアに括ける本格的な騎 馬軍団の創設者となった。この騎馬軍団は, マケ ドニアの軍団で重装備の歩兵部隊と並び独立した 戦術的任務を遂行でさる軍事的な単位となった。 そして良馬を産したテッサリアの部隊一軽騎兵一 はその後，息子アレクサンダーのもとで決定的な 役割を果たすようになった。アレクサンダーは， 彼の馬ブケファルスとともに，アケメネス朝ペル シア軍を撃破，そのペルシア軍の馬を大量に手に 入れることに成功した。それらららニサの馬はぺ ルシア軍の名馬として名高く, カスピ海南方の二 サ平原の馬として知られていた。これらの馬はギ リシアの馬とかけあわせられ，一段と強く，大き 


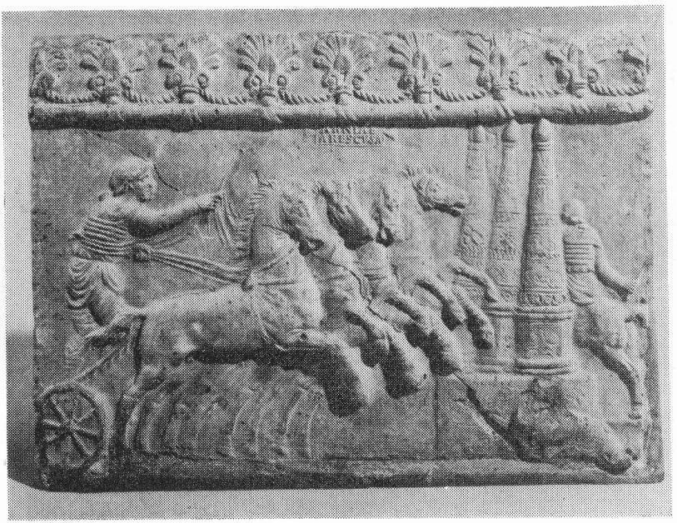

図 21. ターニングポストを回る4 頭立て戦車 テラコッタ，1世紀（ローマ時代） 大英博物館蔵

(Greek and Roman Life-British Museumより)

い馬が生産されるようになり，彼の帝国を築く際 の強力な武器となったことはいらまでもない。そ してアレクサンダー大王の東方遠征と, 後の漢の 武帝の西域遠征により, 東西交涉のシルクロード の道が開かれたのである。

㱍ローマへの車行と騎行の伝播

ローマへの車行，車輪付き運搬具の歴史につい ては，エトルリア文明から考光なければならない。 エトルリア人は小アジアから移住してきて，イタ リア半島のギリシア都市国家との接触により, 戦 車と馬の影響を受けた。

従ってェトルリアの馬車や馬, そして馬具に㧍 いてもギリシアの影響を受忛たが，あるタイプの 銜や馬車は，エトルリアで生まれた。またエトル リアの戦車は, ギリシアの戦車を模倣したもので あったが，やがてローマ人の戦車の原型となり， モデルとなった。

この後ローマでは, ビーガ（ 2 頭立て二輪戦 車）によるレースも盛んであった。ローマ市内に は, キルクス・マキシムスといら最大の競技場が あり， $1,500 \mathrm{~m}$ の走行コースと収容人員 25 万人を 誇ったといら。ローマ人にとって戦車競走はもと もと神事であり, 帝政時代には皇帝が主催する国 家的な行事であった。帝政時代には四チームの間 で競走が行われていた。それぞれのチームは, 赤, 白, 青, 緑の四つに色分けされ, 各チームには熱 狂的なパトロンが付き，オーナーが管理，競技を 運営していた。レースは 1 日12回行われ，1回の

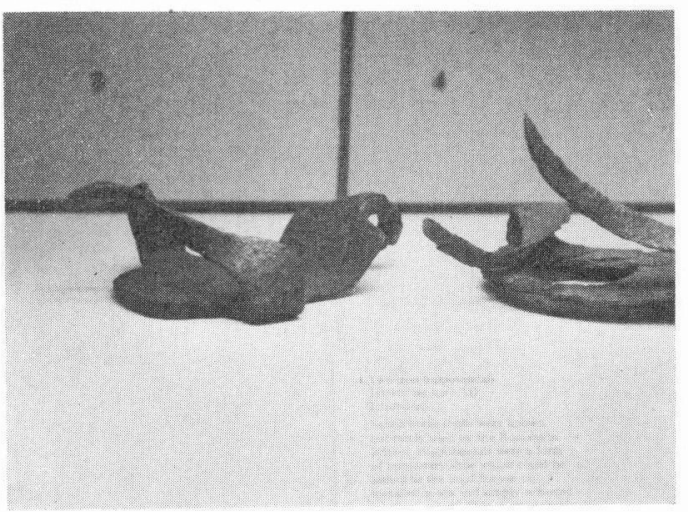

図 22.ヒッポサンダル

鉄製, 1-4世紀, 大英博物館蔵 (筆者撮影)

レースに最大 12 台の戦車が出て 7 周した。通常は 4 頭立の戦車が中心であり (図21)，2 頭立ての 戦車も参加した。とくに皇帝ネロは, 自分のレー スに参加したことが知られている。

ところでローマ人は，クセノフォンと同様馬の 蹄を強くするために注意を払った。とくにローマ は空前の大帝国を結ぶための大道路網を整備, 幹 線だけで $8,500 \mathrm{~km} に も$ 達したが，口ーマ人はそ の幹線道路に石や砂利を敷いた石胃の道路にした ため，馬の蹄の傷みも増加した。そこで伤質が損 われるのを防ぐためローマの農学者コルメルラ （1世紀），ヴァル口（BC 116-26）は，草の繊維 や革で沓を編むことを進めた〔21]。また鉄で作っ たサンダルを馬の足に履くことも行われた(図22)。 スエトニウスの『ローマ皇帝伝』によると, 皇帝 ネロは銀のヒポサンダルを自分の馬にはかせたと する。またプリニウスの『博物誌』は，ネロの愛 妾ポツパエアは自分の馬車を引く馬に金のサンダ ルをはかせたと伝えている。

な和蹄鉄については, ケルトの鉄器時代のラ テース期（BC1世紀）に，オーストリア，ドイッ， ザルッブルグなどから，十数例発見されている 〔4】。この初期の蹄は, 小さく幅 $3 / 4-1 / 2$ インチ, 厚さ $1 / 4$ インチの鉄棒を曲げて作られたもので, 両側にそれぞれ 3 個の釗穴があけられるとしてい る。この鉄製の蹄鉄は，ローマにゲルマン人から 伝えられとするが，たいして使用されなかった。 これが普及するのは中世に入ってからである。

またケルト・ラテー又期は, 乗馬が行われてお 
り，乗用の時に拍車が使用されたことが知られて いる。この拍車は，BC 4 世紀頃からギリシアで 使用されたことが，クセノフォンによって記され ている $[4] 。$

\section{4. ユーラシアの遊牧民の騎行・車行}

ユーラシアの草原で騎馬が盛んになったのは, これまで BC 2,000 年紀の中頃といわれて招り 〔19],ほぼ同期には,インド・ヨーロッパ語族が南 ロシアから移動を開始する。このようにBC2,000 年紀中頃というのは，ユーラシアの世界史で，極 めて重要な位置を占めている。ところが近年デレ イフカの角製品の発見により，未だ断定はできな いが，今後の新たなる発見があれば，騎行の開始 時期がさらに遡る可能性も高い。いずれにしても $\mathrm{BC} 2,000$ 年紀と $\mathrm{BC} 1,000$ 年紀の境目はユーラシ ア草原が遊牧民の世界となる画期と言えよう。

その住民は遊牧生活になじみ，車両を移動した 生活にも慣れ，馬は戦いでも日常生活でも最も重 要な役割を果たすようになる。こうしたスキタイ 時代の始京る以前にも，BC 9 世紀-BC 7 世紀の 前半頃に黒海北岸に住んでいたキンメリア人とい う，インド・ヨーロッパ語族の民族が歴史上記さ れている。すなわち，アッシリア王サルゴン II世 の碑文によれば, BC 720 年頃, メソポタミアの 北方で, 騎馬の遊牧民キンメリアが猛威をふるっ たという。

そして彼らが, 今のところ歴史上, 最も古い遊牧 民と考えられている。このキンメリアの後に，ア ジアの方からスキタイ (BC 7 世紀-BC 3 世紀) と いら本格的な遊牧の騎馬民族が登場する。彼らは アッシリアのエサルハッドンの碑文 (BC 670 年) に出てくるが，これがスキタイの歴史上最初の記 録とされている。そのよらな遊牧騎馬民族はスキ タイだけでなく、ニーラシア草原全域にわたって 分布していた。東はモンゴル高原から西はハンガ リーの草原に至るまで広くステップ地帯に普及し， 東は匈奴，中央アジアにはサカ，月氏などの勢力 が興った。そしてこれらの騎馬民族の出現は, 中 国の秦・漢, 西アジアのアケメネス朝ペルシアな ぞの世界帝国の出現とほぼ同じであった。

この遊牧騎馬民族の特徵を, 林俊雄は, 古代の 二人の偉大な歴史家，へロドトスの『歴史』巻四
と司馬遷の『史記』（洶奴列伝）を対比させなが ら，スキタイと匈奴の共通点を浮彫りにしている。 それによると

1)農耕を行わない純粋の民族である。

2)家畜とともに移動し，定住する町や集落を持た ない。

3)弓矢を武器とし, 全員が騎士である。

4)その戦術は機動性に富及，かつ現実的であって, 不利な時にはあっさり退却する。

へロドトスの『歴史』の完成は BC 430 年, 『史 記』が書かれたのは BC 90 年頃であり，またス キタイの生活舞台はカスピ海北岸から黒海北岸に かけての南ロシア草原であり，一方，仦奴の本拠 地はそこから直線距離でも，5,000-6,000 km 離 れたモンゴル高原にあった。このように遠く隔て られているにもかかわらず，両者は驚くほど類似 しているとしている〔15]。

ところでスキタイの特徴が見られるのは, 武 器・馬具, そして黄金の装身具などだが，これら の中に描かれる題材としては, 動物文様に加えて 騎行する彼らの姿や習俗が大変リアルにとらえら れている。また雪嶋宏一は, 黄金製品について, 「スキタイのこれらの貴金属の多くは，黒海北岸 のギリシア植民都市に住む高度な技術を持った工 人の作品であり, 彼らが使用した若干の道具も発

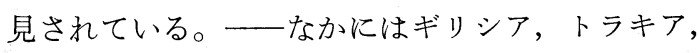
イランなどからの輸入品もあり, アジアからヨー ロッパにまたがる活発な交易圈の存在を裏づけ いる」としている[54]。

その黄金美術の一部を紹介してみると，

-黄金の胸飾りの部分（図23）

このトルスタヤ・モギーラ古墳出土の黄金の胸 飾りには, 上・中・下段にわたってスキタイの遊 牧生活と動物闘争の情景が表わされている。スキ タイは生まれながらの弓の射手であり, 騎土であ り，そして牧夫として四季を通して，彼らの家音 とともに暮らし, そして黒海北岸のステップを移 動する。この胸飾りには牛, 羊, 馬が, それぞれ 子供に乳を飲ませている。左側の馬は後肢で, 身 体をかくようなしぐさを見せ，中央のスキタイ人 は, 彼らの羊革の服を縫う様子が彫られている。

-金管付きの銀のアンフォラ（図24） アンフォラは，銀製，金箔付きの浮彫の図柄で 


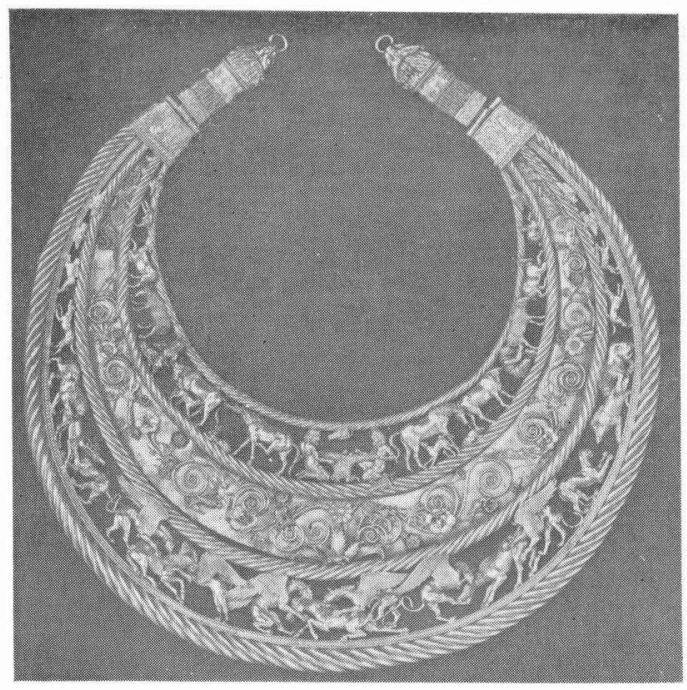

図 23. 黄金の胸飾り（部分） BC 4 世紀，エルミタージュ美術館 (講談社スキタイ黄金美術より)

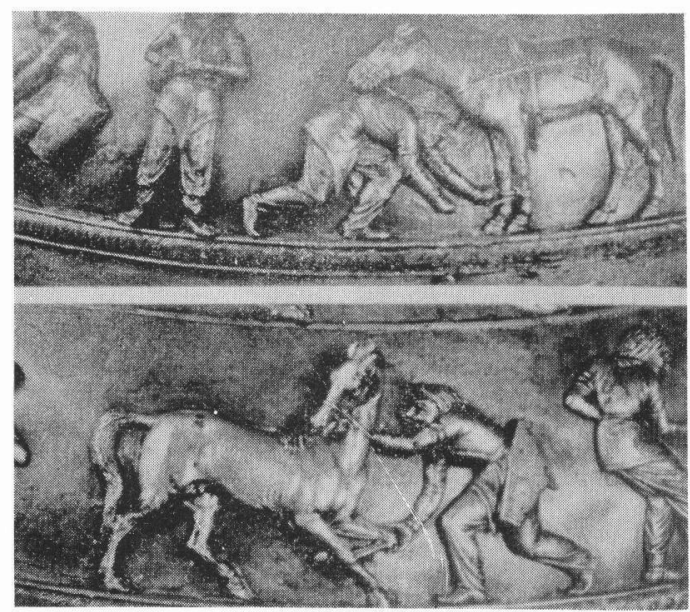

図 24. 金銀製アンフォラ（部分）

BC 4 世紀, エルミタージュ美術館 （講談社，黄金の美術より）

飾られ，上段には空想の有翼怪獣が表わされてい る。そして二段目にスキタイの生活の一部が見ら れる。スキタイ人が馬を捕え，飼いならしていく 過程が順を追って表現されている。初め 2 頭の馬 が放牧され，次に 3 人のスキタイが暴れる 2 頭の 馬を縄でとらえ（縄は失なわれている）ようとし ている。その馬が飼いならされ，馬靱をかけ倒さ れよらとしている。そして馬靬と鞍をつけられた 馬は歩き回らないよらに前足に足かせのような縄

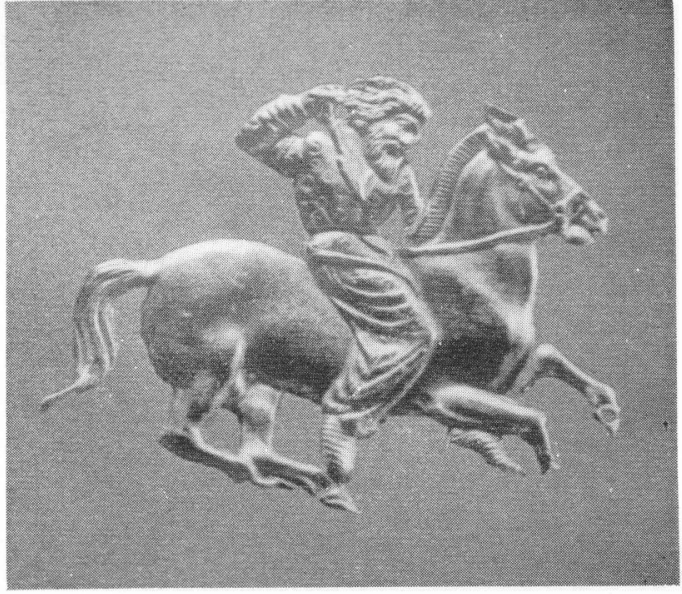

図 25. 黄金のブローチ

BC 4 世紀，エルミタージュ美術館 （講談社，黄金の美術より)

がかけられ（あるいは解かれる）ている。

これらの情景はスキタイ人の生活をよく知って いる優れた技術者によって表現されたものである。

・騎乗のスキタイ人（図25）

またスキタイの戦闘・騎馬術については，へ口 ドトスによって記されているが，彼らは風のよう に現われ，強力な合弓で矢を射たが後を振り向き ざまに矢を射る，いわゆるパルティアンショット を得意とし，恐れられた。

騎乗するスキタイの馬はやや小型だが，クッ ションに近い敷物の上に跨ったスキタイの騎乗ぶ りは，鐙もないが安定している。この黄金美術に 見られる彼らの姿は，活動的な胸の開く上着にズ ボンをはき，腰にはベルトをし，革製のブーツを はいていた。また馬具についても軽快な銜と, クッションを持った軟式の鞍を装着していたこと もわかる。

さて遊牧騎馬民族に関する考古遺物は，スキタ イでは，黑海北岸のチェルトムリク，ソロハ，ケ レルメスなど，匈奴はアルタイ山中のパジリク， トウーヴァ，バシャダル，サカのイッシク，新し いものでは南シベリアのアルジャン古墳等で発見 されて沶り，これらによって，遊牧騎馬民族への 理解も深まっている。

とくにパジリクのクルガンは完全凍結という， 自然の力により現代へ伝えられた。この墳墓には, 当時のアルタイの族長が葬られ，その副葬品には， 
被葬者の自身を飾る黄金などとともに，フェルト， 織物，木製の遺物，それに馬具を装着した馬が副 葬されていた〔15】。

また墓には儀礼用の馬車が副葬されていたが， これは一般用ではなかった。すなわち騎馬民族が 移動に用いる住車とは性格の異なるものであった。 つまりこの馬車は, 葬儀用の馬車と考光られ, 埋 葬する遺体をのせて墳丘の下まで運んだものと されている[42，43]。全てが木製という直径 1.6 $\mathrm{m}$ の巨大な車輪には多数のスポークがあり, 前輪 の心棒が固定されていた。

そして副葬された馬は, 馬車用の小型の馬と乗 馬用の大型の馬があった。十数頭の馬には，いず れも鞍, 木製の鏡板と馬勒, 頭飾りがつけられ, と くに族長の乗ったとされる馬は，大型の馬で胃の 中から穀物も検出されて和り，これらは全て去勢 されていた。この大型の馬は去勢されて大型化し たといら考えもあるが，副葬品に最古のペルシア 䋐求，天幕にもペルシア人らしい容貌の騎士が駿 馬に乗った図などがある点を考慮しても，メディ ア産の馬が交易により数千 $\mathrm{km}$ も離れた地にもた らされていたと考える方が自然であるう。またア ルタイは牧畜がさかんで高品質の羊毛やフェルト が豊富に産出され, このパジリクの鞍にも, 居木 の上にフェルトなどを使って柔らかいクッション をつくり革をかぶせて, 現代の洋鞍に近い軟式の 鞍があった。

このように遊牧騎馬民族スキタイや匈奴の馬と の生活を表わす資料を見てくると, 遊牧騎馬民族 は, 東西の文化交流の重要な役割を持っていたこ とがわかる。すなわちオアシス沿いのいわゆるシ ルクロードが開通したのが前漢の武帝の時代だが， それより以前に既にアルタイを通る草原の道が東 と西の世界を結んでいたのである。

\section{5. 古代中国・朝鮮半島の車行・騎行}

约代古代中国の車行

神話によると中国の車行（車輪付運搬具の使 用) は, 夏王朝以前に遡る。「黄帝」は一族を率 いて戦車で戦場に赴いたと言う。

しかし今のところ, 東アジアでは殷時代 (BC $1,500-1,100$ 年) 以前の考古学的な証拠はない。 実際には殷商代の河南安陽市小屯付近から 2 頭
立て馬車の遺物が出土。また同時代の甲骨文字に は，車とそれを引く馬が表わされており，当時の 中国では既に馬車が普及していたことがわかる。

東アジアの戦車について，林已奈夫[16]および Piggot〔41]などは，ユーラシア大陸を横断して西 アジアからもたらされたとしている。

ところで川又正智は, 殷商後期安陽出土の古代 戦車の構造は, 基本的に同時代あるいはすこし前 の西アジアのものに一致する。すなわち前 2,000 年紀前半一中頃に完成した古代戦車の基本型と称 すべき構造で,

一輈 (1 本ながえ) 衡䡉式の幅式二輪車, 箱形輿（車体）で立乗・後方乗降，馬による 率引で金属製銜使用

2 人以上乗車可能で，車上戦闘および狩猟用の ものであるとする 222$]$ 。またその馬車は基本的に は一致するが，スポークの点では異なり，殷代の 馬車のスポークは20数本というのが普通だが，西 アジアでは10本以上のスポークは稀であるとする。 むしろ最近草原地帯で発掘される殷と同時期か少 し古い遺跡の馬車において，たくさんのスポーク 付車輪が見られることを指摘している[23]。

その後周代までは, 馬車の構造は変わらないが, 殷商代がほとんど 2 頭立ての馬車に対し, 西周に は 2 頭立ての戦車が出現する。周代の馬車につい ては, 東周時代の『周礼考工記』があり, 林已奈 夫が構造・部分名称などを記している[18]。

秦代になると, 秦の始皇帝の兵馬俑坑から陶の 兵馬俑とともに 100 輛をこえる木製の実用戦車が 発見され，車馬文化の発展がわかる。

出土した戦車は, 木質のため, いずれも巧ちて いるが，陝西省博物館で復元されたものを見ると， 車の興（人の乗るところ）, 馬をつなぐ一本の轅 があり, 衡に䡉をしばりつけ，4頭の馬をつない でいた。このように一輛の戦車に 4 頭の馬をつな ぐことは，秦では制度化されていたようである。 また始皇帝陵の大車馬庫から，実物の $1 / 2$ の銅製 馬車と御者が 2 輛分発見されている(図26)。2 輛 とも 1 本轅から成り, 黄金の飾り 747 点, 銀の飾 り 817 点がついていた〔45]。

『史記』などによると，この始皇帝の乗舆は， 第 5 次巡幸の際，華やかな金根車で，数十台の馬 車が従ったという。この秦が滅び，あらたに中国 


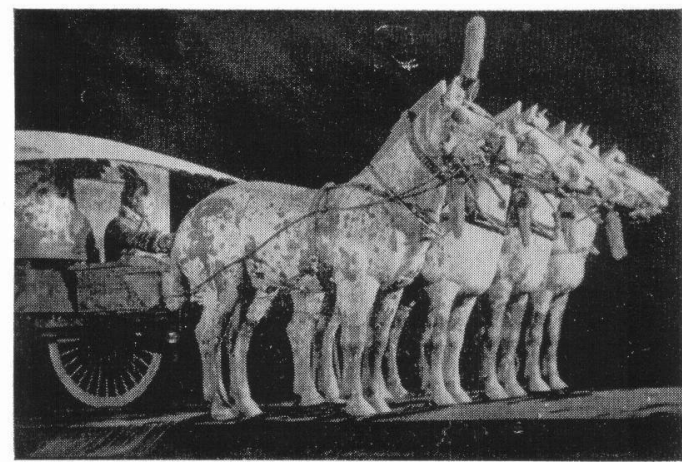

図 26. 秦始皇帝銅車馬

中国・秦, 陝西省兵馬俑博物館蔵 （秦始皇帝銅車馬，中国旅游出版社）

を統一した漢は，北方の匈奴と対立するように なった。

漢は前漢 7 代目の武帝の頃, 最も国力が強大と なり，それまで悩ませられた匈奴を，オルドス， 河西回廊地带から一掃した。また, 戦国期に始ま ったとされる二本轅は, 秦, 前漢にはあまり見ら れないが, 後漢時代に属する画像石などに顕著で ある。その理由としてははっきりしないが，武帝 の時, 大宛 (フェルガナ) の善馬 (西万の馬)を得 るため，大軍を投じ，ついに BC 101 年に善馬数 十頭，中頭馬三千頭を得たことが記されており， 大型で力強い西方種の馬の登場が，戦車の慗駕様 式の革新と関係があったものと考えることもでき よ5。

この後, 中国は機動力のある騎馬を中心とした 世界へ変わっていく。

비쓰. 古代中国の騎行

中国での馬の家畜化は, BC 5,000-3,000 年頃 の仰韶文化期に始まったとされる。陝西省西安の 半坡遺跡から馬の歯や馬骨が発見されており, 住 居趾のすぐそばに，一定の間隔で杭の跡もあり， 家畜化されていたのではないかとされた。しかし この馬骨は野生馬のものとも考光られており, 従って次の龍山文化 (BC 2,500-2,000 年) 頃に は，だいたい馬の家畜化が進んだものと考えられ る。

一方, 中国の騎行については, 草原地带から常 に騎馬民族の脅威を受けながらも, かなり遅れた ようである。先に述べたように農耕地帯の中国は 伝統的に戦車と歩兵の軍隊であった。また中国の
騎行の記録は，一般には BC 307 年の戦国時代の 趙の武霊王が胡服騎手を採用したことが知られ ている。この胡服騎射は遊牧民の服装をし，馬に 跨って矢を射ることを言ら。しかしこれは組織的 行われたことを言っており，これは騎馬民族に騎 馬軍団として対抗するためであり，従って中国に おける騎行が行われたのは甲骨文字などによって ももっと古く, 周あるいは殷の後期頃まで逆る可 能性がある。

ところで中国では，BC 3 世紀の秦以来， 7 世 紀の唐の建国末で，北辺では匈奴，突厥などとの 争いが続くこととなったが，万里の長城を築いた 秦以前, 春秋・戦国時代の騎馬の様子の一例は, 国宝金銀錯狩編文鏡（BC 3 世紀，洛陽出土)[50] に見える，虎と刘峙する騎士にうかがうことがで きる。

さて秦代には，中国の統一をした始皇帝の兵馬 俑坑からは, 步兵, 車兵, そして騎兵が見られる が，騎兵は比率的に少ない。

次の漢代になると，北辺の匈奴が大挙南下する ようになり，これに対抗するには伝統的な重装歩 兵と戦車から成る軍隊では勝負にならなかった。 よって後には同様な騎馬軍団を組織するため，国 内の馬の飼養を積極的に進めた。これにより， 『漢書』(景帝記, 巻 5) 如涼の注によると, 景帝 時代（BC 156-141 年），西北辺郡で大いに馬苑を 興し，その数36力所一養馬30万頭がいたと言う。 また武帝の頃，中央政府が掌握した軍馬40万頭に 達したとされる[53]。

その武帝は, 宿敵匈奴と対決するため大苑( フェ ルガナ）の汗血馬を求めて，大軍を発した。そし て入手した汗馬血（図27）は，今日のアラブ系の 馬の祖先ともいわれている。その後, 前漢以降の 馬の造形表現に，在来種の馬の造形に加えて，西 方の馬, 汗血馬を意識したものが多く表現される よらになった。この後，馬の造形表現は，唐代に は頂点に達する。馬体の表現には，今にも駆けだ さんとする汗血馬や, 躍動感溢孔る天馬（図28） が生き生きとしてとらえられている。唐代には胡 人と馬とを表現した胡人騎馬俑, スポーツとして 流行したポロや婦人の乗馬を表現した俑が造られ た（図29）。

さて馬に騎乗するにあたって，さらに安定し， 


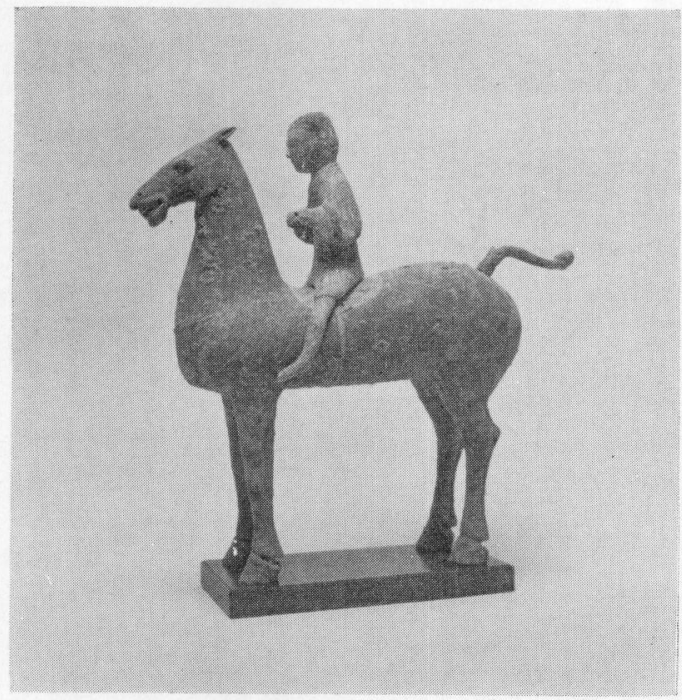

図 27. 騎馬人物俑

中国・漢, 馬の博物館蔵

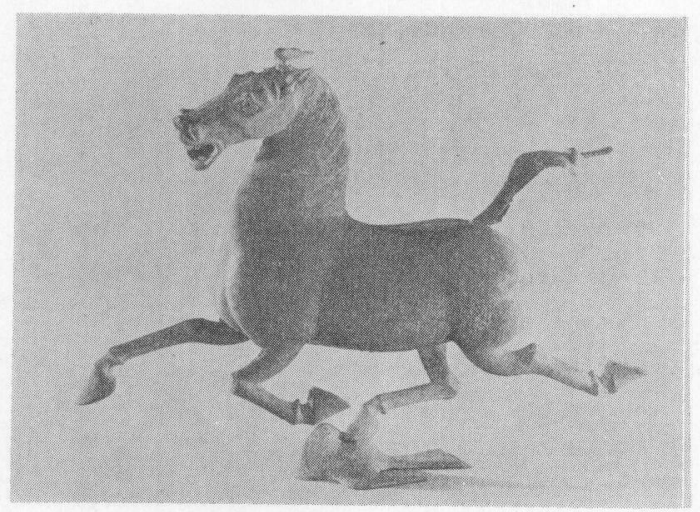

図 28. 飛燕を踏む銅奔馬

中国・後漢, 甘肃省博物館蔵

（中華人民共和国シルクロード文物展より）

戦いに括いては槍を持ら突撃する際に必要なもの は鐙である。

この鐙について, その出現した時期や場所につ いては，考古学界には一致した定説はない。クイ ズラソフによれば, 鐙は, 紀元後 1-2 世紀にサル マタイ人 (BC 4-AD 4 世紀) 頃南ロシア草原地 帯を支配した遊牧民）のもとで発生したとする 研究者もいれば, 後漢の時代に中国と国境を接す る地域を発生地にあげる人も㧍り，なた南シベリ アとする人（BC 3 世紀以前あるいはまた AD 5 世紀),さらに高句麗で (AD 4 世紀以前) に発 明されたとする人もいる。さらにフン族の間では

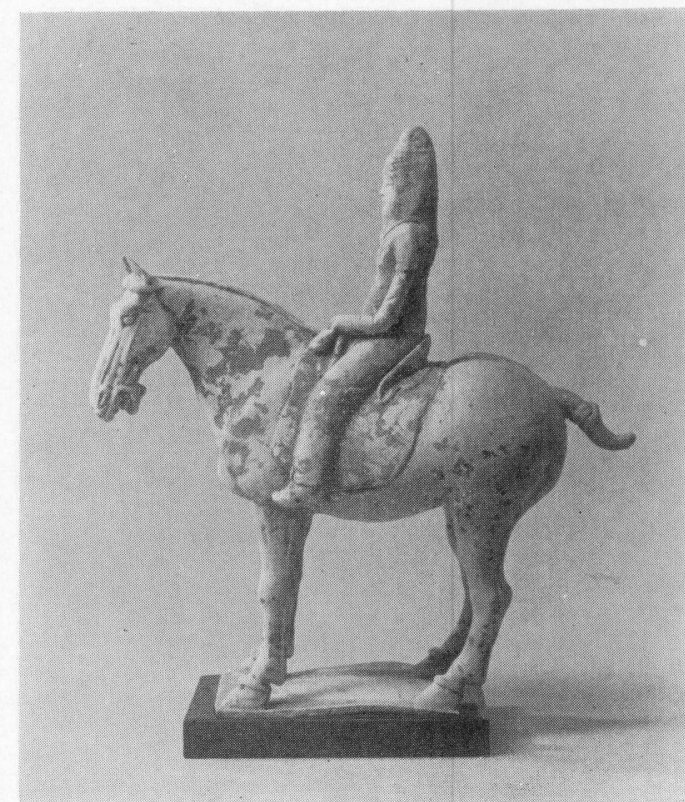

図 29. 女子騎馬俑

中国・唐, 馬の博物館蔵

じめて鐙が出現したとする見解もあり，最後に， 鐙の起源を古代チュルク族（突厥をはじめとする トルコ人系民族）と結びつけて，その発明を 6 世 紀とする人もいる[25]としている。

このように,鐙の起源については, 多くの説があ るが，その当初の使用については片側に紐状のも のを垂らし，乗る時だけに草原の騎馬民族が用い たともいわれている。そして図像や俑では, 漢代 からその表現が見られるものがあるとされていた。

しかし現在知られている考古学的な証拠は晋代, 302年の墓から発見された俑にはっきりした鐙の 形があり，4 世紀のものとしては河南省安陽県孝 民屯のものがある。穴沢咊光はこの鐙は左側だけ にあり，騎士が乗馬する時の足がかりだけに用い たもの，また遼寧省朝陽県遠台子の壁画石槨墓か らは，孝民屯出土のものに似た革製の鞍や鐙など が出土，鐙(左右一対)は藤蔓のようなものを輪に して革で覆ったものらしいとする。また，この 2 例が今のところ古い鐙の実例となっており，形式 的には二つの鐙は, 鐙の吊るす柄の部分がかなり 長く, 日本や朝鮮半島で出土する鐙も, この柄の 長い方が古いとしている[1]。

また二つの古墳から出土する鞍は, 前輪, 後輪, 居木のあるもので, 硬質鞍の古いものと考光られ 


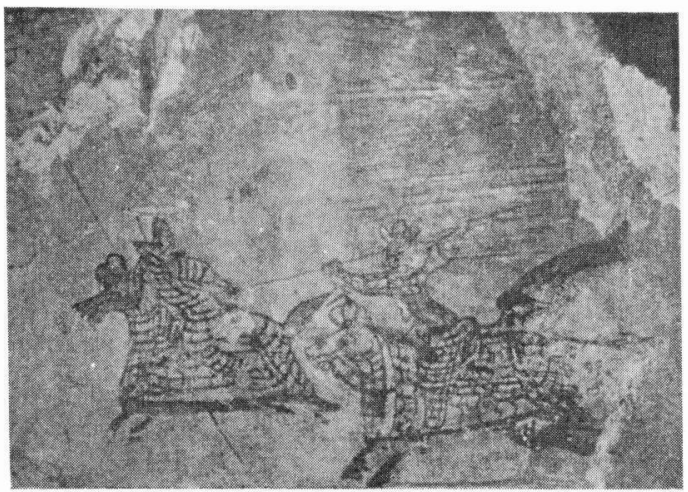

困 30, 三室塚壁画「通溝」より

ている。そしてこのような鞍・鐙が，朝鮮半島や 日本の古墳時代の馬具に影響を与えたものとされ ている。

また中国の戦国時代の始め頃には，革製の馬鎧 が出土しており，馬の甲肯があったことが知られ ており，後の魏晋南北朝には重装の騎兵の装備之 して使われるよらになった。

学朝鮮半島の車行と騎行

漢が中国を統一し，前 108 年に楽浪郡を設置す ると，半島北部へは中国の文化が及ぶようになっ た。漢代文化と直結する青銅製の車馬具が銅剣, 銅矛，そして鉄製利器などとともに土壙墓から発 見された。このよらに車馬の文化は，紀元前数世 紀には, 朝鮮半島へ伝米しているが, しかし森浩 一はこれらの車馬具の出土品が，必ずしも馬車の 使用があったことを意味するものではないとする [35]。その車馬具の内容は，車衡金具，車軸頭， 盍弓帽，銅鐸，馬鐸などであるが，半島南部では 銅鐸，馬鐸の比率が多くなる。おたこれらの車馬 具の一部とされる馬鐸や蓋弓帽が対島のシゲノダ ン遺跡, 下関市の地蔵堂遺跡（弥生時代石棺墓） などから数例発見されている。

一方, 中国の文化が及ぶ以前にも半島北部は北 方からの遊牧騎馬民族の文化の影響を受容してい たものと考えられる。この後半島では三国時代 (高句麗, 新羅, 百済) に入ると, 金属性の銜が 登場し, 騎馬の風習が盛んになる。この三国時代 は高句麗好太王碑文に記されているよらに，騎馬 がさかんで多くの騎兵隊の存在が記されており, また高句麗壁画に見られるよらに騎馬戦（図30） 盛んであったようである。またこれらの壁画に

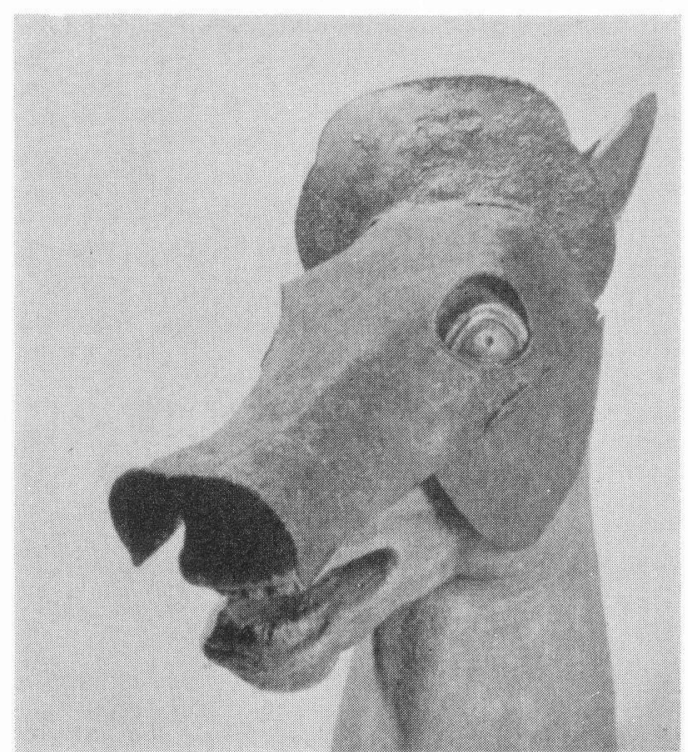

図 31. 馬䡒

陝川玉田28号墳, 三国時代 5 世紀 慶尚大博物館

（よみがえる古代王国，伽耶文化展）

見られる馬具のらち馬の甲胄の実物資料は，伽耶 地方の福泉洞古墳, 玉田古墳群などから出土して いる(戍31)。そしてこれらの馬の甲贯は，日本 へも伝来して扣り, 和歌山県の大谷古墳, 埼玉の 埼玉将軍山古墳から出土している。

中敬澈はこのような高句麗系文物とされる馬の 甲贵が，新羅・伽耶の古墳から発見されるのは， 400 年に高句麗の歩騎 5 万がこの地方に南征した ことを考えなければならない。すなわち高句麗軍 団のこの地方への直接的な南征が，多量の高句麗 文物の移入契機となったとする[47]。

また馬の甲虫とともに出土する半島南部の古式 鐙（福泉洞古墳）は，その源流は中国 4 世紀代の 鐙に求めることがでさ，南部地方で受容され発展 してきた。すなわち三国時代南部地方に騎馬術が 波及したのは 5 世紀初め以降のことである（広開 土王碑文)。そして新羅は 5 世紀初め以降，高句 麗勢力を背景に南部の強者に浮上することになっ た $[47]$ 。

このようにして，5世紀初めに，半島南部で習 得された騎馬術は日本へも波及していった。その 受入れは日本の朝鮮半島への出兵をきっか外とし て学びとったものとされる。なお小野山節は, 騎 
馬の風習が伝わったことを示す馬具は, 5 世紀初 めの古墳の副葬品として初めて現われるので, 騎 馬の風習が 4 世紀末に伝来した可能性はあるとし ている[37]。

また坂本冬美は銜の日本で最もさかのぼる 4 世 紀末から 5 世紀初期の出土品として推定されるも のとして, 福岡県池の上 6 号墳, 同県老司古墳 3 号

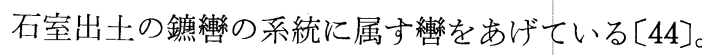

こうしてもたらされた馬具は, 日本に馬具の文 化を開花させることとなった。

なお，縄文・弥生の遺跡から出土する馬の遺体 から, 日本列島には縄文時代や弥生時代に馬が生 息していた，つまり『魏誌』倭人伝の使者が記し た,「牛・馬・虎・豹・鵲無し」は, 誤りであっ たといわれてきた。しかし近年，松井章などの フッ素による新たな再検討の結果, これらの縄 文・弥生期の出土遺物とされていたもので, 年代 の確かなものは古墳時代中期, ほぼ 5 世紀以降の ものとして, 過去の縄文・弥生時代の馬の遺体は 疑問視されるよらになった。

\section{6. 要約と結び}

馬の家畜化の始まりについては, ウクライナの デレイフカの遺物調查から, $\mathrm{BC} 4,000$ 年頃に馬 が役畜として使用された可能性が高まっている。

一方, 車馬の利用については, メソポタミアで,

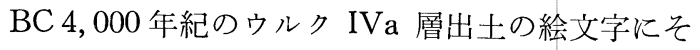
の車輪の表現が見られる。その後シュメールのウ ル王朝の資料等には，板を用いた車輪が見られ， またその馬車や戦車を引くのはロバやオナガーで あったことがわかっている。やがてメりポタミア にも遊牧民との交流で，馬が導入され，逆に車の 文化が草原へ伝えられた。その後バビロニアでは， 戦車にもら少し機動力をもたせたスポーク式車輪 が登場するようになった。このような車輪の改良, そして馬と車とを結びつけたのが，インド・ヨー ロッパ語族系の民族による革新と考兵る研究者の 方が多い。

ところでオリエントでは，伝統的に牛やロバに 車を引かせており, 馬への騎乗も, 牛や口バへの 騎乗涜くものであった。そして BC 1, 500 年頃 から, 騎馬の風習がニーラシアの草原地帯から伝 播し, 西アジアでもルリスタン青銅器文化の金属
性の銜が発明されると，より力の強い馬の制御も 一段と有利となった。

オリェントでは車行に遅れて導入された騎行も, しだいに周辺の文明圈，エジプト，ギリシア，そ してインドへと伝播していった。

これらの車行・騎行の様子は，アッシリアや古 代ギリシアの美術・考古資料に数多く表現されて おり，また実際の車馬の遺物も出土している。

さてニーラシアの草原地帯では, $\mathrm{BC} 2,000$ 年 紀には騎行が盛んになったと考えられているが， 文献上に登場するのは，ずっと後のことである。 BC 8 世紀頃からアッシリアの文献に記されたキ ンメル人, 続いて BC 7 世紀には本格的な遊牧騎 馬民族スキタイが登場する。このような遊牧騎馬 民族は, ニーラシアのステップ地帯の東西に興り, 黒海周辺ではスキタイ, サルマタイ, 中央アジア にはサカ，月氏，そして東は匈奴などが勢力を 奮った。これらの騎馬民族の生活, 習俗は, 黒海 周辺やアルタイ山中の多くのクルガン (墳墓) 出 土の黄金製品などに見ることができる。

中国での馬の家畜化は，神話によると夏王朝以 前にさかのぼるとされるが，殷商代（BC 1,500 年) 以前に考古学的な証拠はないとされる。そし て実際の馬車は, 河南省安陽市から殷商代のもの が見つかって抢り，また同時代の甲骨文字には， 既に馬車の表現が見られる。

ところで東アジアの馬車は, 基本的には西アジ アの馬車と一致するが，馬車のスポークは東アジ アのものに多数のスポークが見られ，とくにステ ップ地带にはその古い証拠が発見されている。こ の馬車は, 中国で周代に発展を遂げ, 秦代にはその 頂点とも言える始皇帝の銅車馬が出土している。 この後, 中国を統一した漢は, 伝統的な重装歩兵と 戦車から成る軍隊を改革, 同様な騎馬軍団を組織, ついに BC 101 年には, 西方の汗血馬, または天 馬と呼ばれる名馬を入手する。その名馬の図像は, 以降，壁画や俑に多く表現されるようになった。

朝鮮半島へも中国の影響が見られ, 楽浪郡跡か ら車馬具が出土している。一方, 半島北部は, 北 方からの騎馬民族の影響を受けていたと考兄られ るが，半島でも三国時代（高句麗，新羅，百済） に入ると騎馬の風習が盛んになる。その様子は高 句麗壁画に見られ，実際の馬胄も出土。そしてこ 
の馬旮やその他の馬其は，5世紀以降には，日本 にも伝えられるよらになった。こうしてもたらさ れた馬具は，その後の日本の馬具の文化を開花さ せることとなった。

最後に，このたび美術・考古資料により古代の 騎行・車行について，紹介してきたが，馬と人間 の織りなす壮大な歴史や文化を紹介するには，や や図版不足が否めなかった。但し，近年の研究成 果も含めて，その一端なりとも紹介できたと思う。

ところでそれぞれの資料に表わされた馬の図像 については，誇張されたり，形式化されたものも 多い。また馬と人間の歴史を見ても，馬は，当時 の支配者達によって求められ，何十回となく移動 され，改良されたことが文献上からも推測される。

よって今後は，近年著しく発展を遂げた科学技 術を用いた考古学的なアプローチと併せ，文献上 による人の手に成る移動も抑えながら，古代の馬 の実像と, 騎行・車行の歴史に迫まれることを望 みたい。

\section{引用文献}

1. 穴沢咊光 (1984). 東と西の民族移動時代一東晋(五 胡）十六国の考古学. 14-20頁，東方書店，神田。

2. Anthony, D.W. (1991). The archaeology of IndoEuropean origin. J. Indo-European Studies 19(3/4) : 193-222.

3. Anthony, D. W. and Brown, D. R. (1991). The origins of horseback riding. Antiquity $65: 22-38$.

4. Azzaroli, A. (1985). An Early History of Horsemanship. E. J. Brill, Leiden.

5. Bökönyi, S. (1978). The ealiest waves of domestic horse in East Europe. J. Indo-European Studies 6 : 17-73.

6. Glutton-Brock, J. (1981). Domesticated Animals from Early Times. pp. 80-90, British Museum and Heinemann, London.

7. Clutton-Brock, J. (1989). 増井久代訳, 増井光子 監修, 図説動物文化史辞典. 人間と家畜の歴史 127 146頁, 原書房.

8. Dalley, S. (1984). Mari and Karana Two Old Babylonian Cities, Longman, London and New York.

9. Dossenbach, M. and Hans, D. (1985). The Noble Horse, pp. 110-113, G. K. Hall, Boston, Massachusetts.

10. Downs, J.F. (1961). The origin and spread of ridding in the Near East and Central Asia. Am. Anthrop. 63 : 1193-1203.

11. Falkenstein, A.(1936). Ausgrabungen der Deutsch Farschungsgemeinschaft in Urk-Warka, 1, Archaische Texte aus Uruk.

12. Gorcacht, W. (1976). Das Abenteur Pferd, Das Pferd bei den Assyrean, pp. 17-36, Limpert Verlag
Gmbh Bad Homburg V.D.H, Alle Rechte Vorbehaltt.

13. Gorbacht, W. (1976). Das Abenteur Pferd. Das olympisch Götter schönstes Geschenk, pp. 37-100, Limpert Verlag Gmbh Bad Homburg V. D. H. Alle Rechte Vorbehalten.

14. Gorbacht, W. (1976). Das Abenteur Pferd. Die LPG des Kikkuli, pp. 24-29, Limpert Verlag Gmblt, Bad Homburg V. D. H. Alle Rechte Vorbehalten.

15. 林 俊雄 (1990). 草原の民一古代ニーラシアの騎 馬民族，中央ユーラシアの世界民族の世界史 4，2658頁, 山川出版.

16. 林 已奈夫 (1959). 中國先秦時代の馬車. 東方学 報。

17. 林 已奈夫 (1959-1960). 中國先秦時代の馬. 民 族学研究 23-4, 24-1.2.

18. 林 巳奈夫 (1967). 西周全文に現れる車馬関係語 彙，甲骨學 11 .

19. 加藤九祚 (1989). 遊牧騎馬民族の民. 週刊朝日百 科世界の歴史 19 , 朝日新聞社。

20. 加茂儀一 (1973)。家童文化史. 改造社.

21. 加茂俄一 (1980). 騎行車行の歴史. 法政大学出版 局.

22. 川又正智 (1992)。古式草原地帯の輻式車輛. 教養 論集第 35 号，國士舘大学教養学会教養論集第 35 号.

23. 川又正智 (1987). 載駆薄薄一東アジアの古代戦車 と西アジア古史春秋 4

24. Kowalski, K. (1967). The Pleistocene Extinction of Mammals in Europe. Martin, P. S. and Wright, H. E. (eds.), Yale University Press, New Haven.

25. Kyzlasov, I. L. (1973). 鐙の起源について, 中世 初期ユーラシア草原に和ける馬具の発達, 林俊雄 編 訳. 馬事文化財団 馬の博物館叢書.

26. Langdon, S. (1924). Excavations at Kish 1, Vol. IV. Paris.

27. Levin, M. A. (1983). Mortality models and the interpretation of horse population structure. In G. Bailey(ed.), Hunter-gatherer Economy in Prehistory, pp. 23-46, Cambridge University Press.

28. Levin, M. A. (1990). Dereivka and the problem of horse domestication. Antiquity $64: 727-740$.

29. Littaurer, M. A. and Crouwel, J. H. (1977). Origin and diffusion of the cross-bar wheel? Antiquity 51 : 95-105.

30. Littaurer, M, A. and Crouwel, J. H. (1979). Wheeled Vehicle and Ridden Animals in the Ancient Near East. E. J. Brill, Leiden.

31. 松井 章 (1992). 動物遺存から見た馬の起源と普 及. 日本馬具大鑑 $1: 33-44$, 吉川弘文館.

32. 松原千秋 (1993)。 ヘロドトス歴史(中)，岩波文庫 33-405-2, 岩波書店.

33. Mellaart, J. (1981). Anatolia and the IndoEuropean. J. Indo-Enropian Stndies 9 : 135-149.

34. Moorey, P. R. S. (1986). The emergence of the light, horse-drawn chariot in the Near-East c 20001500 BC World Archaeology XVIII-2 : 196-215.

35. 森 浩一 (1974). 日本古代文化の探究「馬」. 4854頁, 社会思想社.

36. Morgan, M. H.(1962). The art of horse-manship 
by Xenophon. Translated, With chapters on the Greek Riding horse and with notes. J. A. Allen and Company Limited, London.

37. 小野山 節 (1992). 古墳時代の馬具. 日本馬具大 鑑 1:1-32, 吉川弘文館.

38. Piggot, S. (1968). The Earliest Wheeled Vehicles and the Caucasian Evidence. Proc. Prehist. Soc. XXXI, Cambridge.

39. Piggot, S. (1968). The Begginings of Wheeled Transpor（福本剛一郎 訳 1976 「人類最初の車」『別 冊サイエンス特集考古學文明の遺産』.

40. Piggot. S. (1974). Chariots in the Caucasus and in China. Antiquity, XLVIII. Oxford.

41. Piggot, S. (1983). The Earliest Wheeled Transport from the Atlantic Coast to the Caspian Sea. London.

42. Rudenko, S. I. (1953). The Culture of the Peoples of the High Atlai in the Scythian Period. Moscow.

43. Rudenko, S. I. (1960). The Culture of the Peoples of the Central Altai in the Scythian Pericd. Moscow.

44. 坂本冬美 (1985). 馬具. 考古学ライブラリー 34 , ニュー・サイェンス社.

45. 陝西省秦俑考古隊他 (1983). 秦陵二號銅車馬. 考 古與対物羡刊第一号.

46. Sherratt, A. G. (1981). Plough and pastoralism : aspect I. of the secondary products revolution. In
Hodder, I. et al.(eds), Patterns of the Past: Studies in honour of David Clarke. pp. 261-305. Cambridge: Gambridge University Press.

47. 申 敬澈 (1986). 古代文化 第38巻 6 号.

48. 謝 成俠, 千田英二訳 (1957). 『中国養馬史』日 本中央競馬会弘済会.

49. 末崎真澄 (1987). 古代の美術に括ける馬の伝統的 表現. 馬事文化財団 馬の博物館研究紀要第 1 号 : 912.

50. 末崎真澄 (1987). 馬の美術名品展. 月刊文化財 7, 文化庁文化財保護部監修 第一法規出版.

51. Tarr，L. 野中邦子訳 (1991). 馬車の歴史. 平凡 社.

52. Telegin, D. Y. (1986). Dereivka : A Settlment and Cemetery of Copper Age Horse Keepers on the Middle Dnieper. Oxford: British Archaeological Report. International series S 287.

53. 王 仁波 (1984). 中国歴代の陶俑について，中国 陶俑の美, 朝日新聞社.

54. 雪嶋宏一 (1989). 黄金の器物にみるスキタイの暮 らし. 週刊朝日百科. 世界の歴史 19. 遊牧騎馬の民. 朝日新聞社.

55. Zarins, J. (1976). The domestication of equidae in third millennium B. C. Mesopotamia. Thesis no T-26263, Joseph Rogenstein Library, University of Ghicago. 